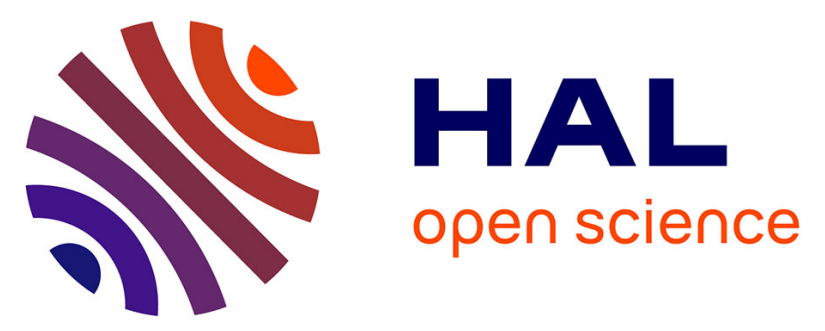

\title{
The Neoproterozoic Upper Ruvubu Alkaline Plutonic Complex (Burundi) revisited: large-scale syntectonic emplacement, magmatic differentiation and late-stage circulations of fluids
}

Sophie Decrée, Daniel Demaiffe, Luc Tack, Gérard Nimpagaritse, Paul de Paepe, Philippe Boulvais, Vinciane Debaille

\section{To cite this version:}

Sophie Decrée, Daniel Demaiffe, Luc Tack, Gérard Nimpagaritse, Paul de Paepe, et al.. The Neoproterozoic Upper Ruvubu Alkaline Plutonic Complex (Burundi) revisited: large-scale syntectonic emplacement, magmatic differentiation and late-stage circulations of fluids. Precambrian Research, 2019, 325, pp.150-171. 10.1016/j.precamres.2019.02.023 . insu-02051890

\section{HAL Id: insu-02051890}

\section{https://hal-insu.archives-ouvertes.fr/insu-02051890}

Submitted on 28 Feb 2019

HAL is a multi-disciplinary open access archive for the deposit and dissemination of scientific research documents, whether they are published or not. The documents may come from teaching and research institutions in France or abroad, or from public or private research centers.
L'archive ouverte pluridisciplinaire HAL, est destinée au dépôt et à la diffusion de documents scientifiques de niveau recherche, publiés ou non, émanant des établissements d'enseignement et de recherche français ou étrangers, des laboratoires publics ou privés. 


\section{Accepted Manuscript}

The Neoproterozoic Upper Ruvubu Alkaline Plutonic Complex (Burundi) revisited: large-scale syntectonic emplacement, magmatic differentiation and latestage circulations of fluids

Sophie Decrée, Daniel Demaiffe, Luc Tack, Gérard Nimpagaritse, Paul De Paepe, Philippe Boulvais, Vinciane Debaille

PII: $\quad$ S0301-9268(18)30566-7

DOI: $\quad$ https://doi.org/10.1016/j.precamres.2019.02.023

Reference: $\quad$ PRECAM 5298

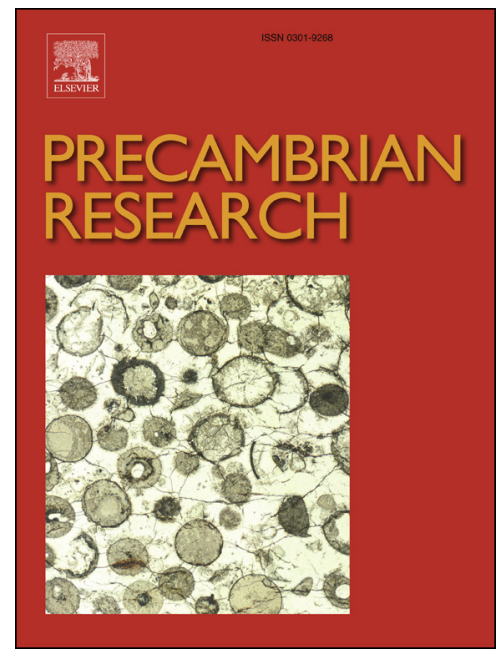

To appear in: $\quad$ Precambrian Research

Received Date: $\quad 31$ October 2018

Revised Date: $\quad 19$ February 2019

Accepted Date: $\quad 21$ February 2019

Please cite this article as: S. Decrée, D. Demaiffe, L. Tack, G. Nimpagaritse, P. De Paepe, P. Boulvais, V. Debaille, The Neoproterozoic Upper Ruvubu Alkaline Plutonic Complex (Burundi) revisited: large-scale syntectonic emplacement, magmatic differentiation and late-stage circulations of fluids, Precambrian Research (2019), doi: https://doi.org/10.1016/j.precamres.2019.02.023

This is a PDF file of an unedited manuscript that has been accepted for publication. As a service to our customers we are providing this early version of the manuscript. The manuscript will undergo copyediting, typesetting, and review of the resulting proof before it is published in its final form. Please note that during the production process errors may be discovered which could affect the content, and all legal disclaimers that apply to the journal pertain. 


\section{The Neoproterozoic Upper Ruvubu Alkaline Plutonic Complex (Burundi) revisited:}

\section{large-scale syntectonic emplacement, magmatic differentiation and}

\section{late-stage circulations of fluids}

Sophie Decrée ${ }^{1, *}$, Daniel Demaiffe ${ }^{2}$, Luc Tack ${ }^{3}$, Gérard Nimpagaritse ${ }^{3}$, Paul De Paepe ${ }^{4}$, Philippe Boulvais $^{5}$ and Vinciane Debaille ${ }^{2}$

${ }^{1}$ Royal Belgian Institute of Natural Sciences, Brussels, Belgium

* Corresponding author: sdecree@ naturalsciences.be

${ }^{2}$ DGES - Laboratoire G-Time (CP 160/02), Université Libre de Bruxelles (ULB), Brussels, Belgium

${ }^{3}$ Royal Museum for Central Africa (RMCA), Tervuren, Belgium

${ }^{4}$ Department of Geology, Ghent University, Ghent, Belgium

${ }^{5}$ University of Rennes 1, Rennes, France,

\section{Abstract}

The Upper Ruvubu Alkaline Plutonic Complex (URAPC) in Burundi consists of three separate intrusions, each with a specific emplacement age and petrological composition. Three main units are recognized: an outer unit with silica-saturated plutonic rocks (from gabbro to granite), an inner unit with silica-undersaturated plutonic rocks (feldspathoidal syenite with subordinate feldspathoidal monzonite and ijolite) and a carbonatitic body in the subsoil, known by drilling. The URAPC is quite large in size $(\sim 24 \mathrm{~km}$ long and up to $10 \mathrm{~km}$ wide). It is considered to have been intruded syntectonically in an overall extensional context, thanks to the kilometric shear zones that accommodated its emplacement. Radiometric ages from literature range from 748 to $705 \mathrm{Ma}$ and point to structurally-controlled magmatic differentiation followed by long-lived circulations of late-stage fluids postdating the 
emplacement of a part of the undersaturated rocks and the carbonatites. In the north-western part of the outer unit, gabbro likely has been emplaced at a deeper structural level than the granite, which represents a more apical structural level of emplacement.

This petrological, geochemical and isotopic (Sr-Nd-Hf) study concentrates on the processes that generated the URAPC: (i) fractional crystallization, evidenced by the chemical evolution trends of the major and trace elements, and by marked $\mathrm{P}$, Ti and $\mathrm{Ba}$ anomalies in the trace element patterns; (ii) crustal assimilation/contamination, as shown by the wide range of $\mathrm{Nd}$ isotope compositions and the general increase of the $\mathrm{Sr}$ isotope ratios with increasing $\mathrm{SiO}_{2}$ contents, and (iii) late-magmatic/hydrothermal alteration inducing an increase of the $\mathrm{Sr}$ isotope composition without changing significantly the $\mathrm{Nd}$ isotope composition.

The isotopic data are consistent with an asthenospheric mantle source, though less depleted than the Depleted Mantle (DM), contaminated by the Subcontinental Lithospheric Mantle (SCLM). The silicate and carbonate magmatic series are cogenetic. The outer unit is clearly more contaminated than the inner unit, whereas the carbonatitic body could have evolved by liquid immiscibility.

The URAPC lies within East Africa's Western Rift Valley, which is marked by 23 alkaline plutonic complexes. Their emplacement has been ascribed to reactivation of Proterozoic lithospheric weakness zones resulting from the breakup of the Neoproterozoic supercontinent Rodinia supercontinent.

Keywords: Neoproterozoic, carbonate-silicate melt immiscibility, fractional crystallization, crustal contamination/assimilation, SCLM, Sr-Nd-Hf isotopes.

\section{Introduction}


More than 850 alkaline complexes with or without associated carbonatites have been identified in Africa (Woolley, 2001). They represent about $40 \%$ of all occurrences worldwide. Their ages range from 2 billion years (Ga) (Phalaborwa, South Africa) to the present day (Oldoinyo Lengai, Tanzania), with a marked abundance peak pointing to the Neoproterozoic and the Lower Paleozoic (roughly 850-500 millions years (Ma); Midende et al., 2014). The tectonic context at the time of emplacement of the Upper Ruvubu Alkaline Plutonic Complex (URAPC; around 700Ma; Midende et al., 2014) is likely related to rifting during Rodinia breakup; this setting also explains fairly well the peak of age emplacements between 850 and $500 \mathrm{Ma}$.

As a rule, the geometry of the many alkaline complexes in East Central Africa is subcircular, with an average size not exceeding $\sim 10 \mathrm{~km} \mathrm{x} \sim 8 \mathrm{~km}$ (although some complexes are around 20-25 km across), and all these complexes are spatially associated with the East African Rift (Woolley, 2001). Along the western branch of this rift system, 23 Neoproterozoic alkaline plutonic complexes, including the Upper Ruvubu Alkaline Plutonic Complex (URAPC), are distributed over a distance of $\sim 1700 \mathrm{~km}$ (Tack et al., 1984; Kampunzu et al., 1985).

The URAPC consists of three major units (Fig. 1): an outer unit, predominantly composed of quartz-bearing syenite, granite and gabbro-diorite, an inner unit of feldspathoidal syenite, and a small carbonatitic body (called Matongo carbonatite) that presently is not outcropping but only known by drilling. The URAPC differs from many other alkaline complexes by its outstanding dimensions ( 24 km long x $10 \mathrm{~km}$ wide) and elliptical shape (Tack et al., 1984; Midende et al., 2014). These geometric attributes have been related to syntectonic emplacement conditions accommodated by the development of large shear zones (Boulvais et al., 2015; Decrée et al., 2015). This occurred in the overall extensional tectonic regime that affected a broad region of Central Africa during Rodinia breakup (Burke et al., 2003; Tack et al., 1996). This model is consistent with the general context of emplacement considered for 
alkaline complexes (distensive regions associated or not with rifts; Black et al., 1985). The URAPC was emplaced between $\sim 748$ Ma and $~ 705$ Ma (Tack et al., 1984; 1996; Demaiffe, 2008; Midende et al., 2014) and is ascribed to reactivation of Proterozoic lithospheric weakness zones during the breakup of the supercontinent Rodinia (Tack et al., 1984; 1996; Kampunzu et al., 1985; Midende et al., 2014).

The present paper complements recent studies dealing with various aspects of the URAPC (Midende et al., 2014; Boulvais et al., 2015; Decrée et al., 2015 and 2016). It presents a comprehensive petrographical, mineralogical and geochemical (major and trace elements, and radiogenic isotopes) study of the complex. $\mathrm{Sr}, \mathrm{Nd}$ and $\mathrm{Hf}$ isotope compositions of the three units mentioned above were determined in order to identify the source of the parental magma(s), to test the cogenetic nature of the whole suite of rocks, and to evaluate the extent of crustal contamination (if any) that took place during the emplacement and the differentiation processes. In the light of the syntectonic emplacement of the complex, the impact of circulation of late-stage magmatic fluids is discussed too.

\section{Geological setting}

\subsection{Regional geology}

The Neoproterozoic Upper Ruvubu Alkaline Plutonic Complex (Fig. 1) is located in NW Burundi along the Western Rift. Field mapping shows that it intruded the Western Domain of the Karagwe-Ankole Belt, known to consist of Mesoproterozoic metasedimentary and metavolcanic rocks (Akanyaru Supergroup, Gikoro and Pindura groups; Fernandez-Alonso et al., 2012). The rocks attributed to these groups were intruded by S-type granites (e.g. Kayanza granite) linked with the $\sim 1375$ Ma intraplate bimodal magmatic extensional "Kibaran event" associated with asthenospheric upwelling (Tack et al., 2010). At 1000 Ma, peraluminous 
granites intruded the Karagwe-Ankole Belt in a regional collisional context (Debruyne et al., 2015). In the Western Domain, intrusion of the tin granites is dated at $\sim 986 \mathrm{Ma}$ (Tack et al. 2010). The tin mineralization developed in a quiescent setting following the paroxysm of deformation (Dewaele et al., 2011; Melcher et al., 2015). Both the magmatism and the foldand-thrust belt geometry of the Karagwe-Ankole Belt have been ascribed to a far-field effect of Rodinia amalgamation. They illustrate the convergence between the Congo and TanzaniaBangweulu Cratons, regionally marked by the $\sim 1.0$ Ga Southern Irumides collisional orogeny (Fernandez-Alonso et al., 2012). For the Kibara Belt, which is separated along trend from the Karagwe-Ankole Belt over a distance of $300 \mathrm{~km}$ by older terranes (Palaeoproterozoic Rusizi belt), geochemical and isotopic data point to a subduction setting (Debruyne et al., 2015).

At $\sim 800-750 \mathrm{Ma}$, the emplacement of alkaline complexes in the western branch of the East African Rift is overall related to the Rodinia breakup and continental rifting (e.g., Burke et al., 2003; Kampunzu et al., 1997; Tack et al., 1996), with the possible involvement of a superplume present below Rodinia (Bell, 2001; Ernst and Buchan, 2003; Li et al., 2008). Nevertheless, the breakup appears to be diachronous with a succession of extensional regimes (e.g., Delpomdor et al., 2013).

As a result of the $\sim 550 \mathrm{Ma}$ Gondwana amalgamation, N-S trending discrete thrust sheets and imbricate structures have overprinted large areas of the Karagwe-Ankole Belt, amongst others in NW Burundi (Fernandez-Alonso et al., 2012).

The URAPC has a roughly NW-SE oriented elliptic shape (Fig.1A). Three magmatic units have been distinguished: an "outer" silica-saturated unit, an "inner" silica-undersaturated unit and a rather small carbonatite body in the subsoil, referred to as Matongo carbonatite (Tack et al., 1984 and references therein; Fig.1B). The NW-SE trending elongate outer unit is an intimate association of plutonic rocks ranging from olivine-bearing gabbro and diorite through 
quartz-bearing syenite to granite (Figs.2A-D). The spatially more limited N-S trending ellipsoidal "inner" unit consists of feldspathoidal syenite and a subordinate amount of feldspathoidal monzonite (Figs.2E-G). It cross-cuts the outer unit and forms the core of the URAPC complex. Concentric subvertical magmatic layering suggests rapid emplacement conditions (Fig.2E) with very little (if any) contamination from (and interaction with) rocks from the outer unit when the inner feldspathoidal syenite intruded. The outer unit is outcropping in two parts of the URAPC, i.e. in the SE (Buraniro granite, displaying a large crescent-shaped external zone) and in the NW (Maranga granite, extending over a more limited external area). In the field, no cross-cut limits are observed between the gabbro, diorite, quartz-bearing syenite and granite, but rather a progressive transition (Tack et al., 1984). Xenoliths deriving from the outer unit occur in the inner unit, whereas numerous dykes of feldspathoidal syenite (with sharp/clear-cut contacts) intrude the outer unit, especially in its NW part. When observable, the contacts of outer unit with the surrounding metasedimentary parent rocks (in particular to the west of the massif) are often tectonized with more or less well-expressed foliation. The extent of the elongate N10E trending Matongo carbonatite body, originally discovered by geophysics, has been revealed by drilling campaigns showing a 2750 m long and $250 \mathrm{~m}$ wide, dyke-like intrusive body with subvertical magmatic layering. Fine- and coarse-grained calciocarbonatites and a ferrocarbonatite have been identified in the Matongo carbonatite body (Midende, 1984; Demaiffe, 2008; Midende et al., 2014). About 3 $\mathrm{km}$ to the north of the Matongo carbonatite (Fig. 1B), a magmatic breccia, surrounded by feldspathoidal syenites of the inner unit, contains carbonatitic veinlets suggesting that the Matongo carbonatites postdate the emplacement of the inner unit.

Quartz-bearing syenites of the outer unit, kaolinized by hydrothermalism, are exposed at the surface and locally capped by a supergene lateritic crust (Inamvumvu laterite; Fig.1B). The area of kaolinization coincides with a metasomatic aureole (fenitisation) appearing on top of 
and around the Matongo carbonatite. Kaolonization seems associated with the location of deformed zones. These are vertical shear zones, several kilometres long, tens of metres wide (Fig.1B; Decrée et al., 2015). They controlled the emplacement of the URAPC and hence its present-day geometry. Kaolinization was likely enhanced by fluid circulation along these zones of high permeability. Secondary phosphates occur on top of the carbonatite body. Isolated megacrysts of zircon and ilmenite (up to $6 \mathrm{~cm}$ in size) have been found in laterite and kaolin in the Inamvumvu area $(\sim 1 \mathrm{~km}$ north of the Matongo carbonatite and $\sim 1 \mathrm{~km}$ south of Kiziba; Fig. 1B). Although referred to as "Matongo zircons" (Fransolet and Tack, 1992; Burke, 1998; Midende et al., 2014), these megacrysts do not come from the Matongo carbonatite body itself but are likely linked with pegmatoid veinlets intruding the kaolinized quartz-bearing syenite, as observed during carbonatite exploration works in the 1980s (British Sulphur Company, unpublished internal report). A genetic relationship with the carbonatite body is corroborated by the nature of their primary carbonate inclusions (Burke, 1998) pointing to a relatively late-stage circulation of fluids originating from the nearby Matongo carbonatite body.

Beside fenitisation, phosphate mineralization and pegmatoid veinlets containing megacrysts evidence of late-stage fluid circulations and alterations is obvious in the field (Fig.1B), as: (i) local enrichment in blue sodalite and yellow or pinkish cancrinite, and in garnet and associated clinozoïsite-epidote in feldspathoidal syenites (in the southern portion of inner unit); and (ii) carbonatite veinlets and related breccias with their hydrothermal REE-Sr mineralization (with monazite, ancylite and strontianite) in the feldspathoidal syenites (north of Kiziba).

\subsection{Geochronology and isotope geochemistry}


The emplacement ages of the outer and inner units of the URAPC have been determined in the 1980-1990s. These ages, although not recent, can still provide a useful indication of the emplacement age of the complex. The inner unit gave a U-Pb bulk zircon age of $739 \pm 7 \mathrm{Ma}$ (Tack et al., 1984) and the outer unit an age of $748 \pm 2$ Ma (Buraniro granite, SE part of the outer unit; unpublished data, and Tack et al., 1995). A fission-track age of $762 \pm 33 \mathrm{Ma}$ obtained on titanite from the inner unit (Van den haute, 1986) overlaps with the $739 \pm 7 \mathrm{Ma}$ age, whereas an unpublished zircon $\mathrm{Pb}$-evaporation age of $741 \pm 2 \mathrm{Ma}$ obtained for the Buraniro granite (Tack et al., 1995) is in line with the $748 \pm 2 \mathrm{Ma}$ age. The Rb-Sr whole rock isochrons for the inner and outer units of the URAPC converge to $700 \mathrm{Ma}$, respectively 699 $\pm 13 \mathrm{Ma}(\mathrm{MSWD}=5.2)$ and $707 \pm 17 \mathrm{Ma}(\mathrm{MSWD}=1.6)($ Tack et al., 1984).

The "Matongo zircon" megacrysts (see 2.1) yielded a LA-ICP-MS U-Th-Pb age of $705.5 \pm$ 4.5 Ma (Midende et al., 2014), which is inferred (see 2.1.) to be a minimum age for the crystallization and emplacement of the Matongo carbonatite body. This age is consistent with the $\mathrm{Pb}-\mathrm{Pb}$ whole rock isochron age of $690 \pm 32 \mathrm{Ma}$ obtained on the carbonatites (Demaiffe, 2008) and matches with the Rb-Sr whole rock ages of the inner and outer units $(699 \pm 13 \mathrm{Ma}$ and $707 \pm 17 \mathrm{Ma}$, respectively). An unpublished zircon Pb-evaporation age of $738 \pm 4 \mathrm{Ma}$ obtained on similar megacrysts (Tack et al., 1995), although less precise, could suggest a slightly older age for the carbonatite body.

If the bulk zircon $\mathrm{U}-\mathrm{Pb}$ ages obtained for the inner and outer units (respectively $739 \pm 7 \mathrm{Ma}$ and $748 \pm 2 \mathrm{Ma}$ ) are considered to be reliable emplacement ages, the significantly younger $\mathrm{Rb}-\mathrm{Sr}$ "ages" of the same units could then correspond to the resetting of the primary (= magmatic) $\mathrm{Rb}-\mathrm{Sr}$ ages as a result of the emplacement, at $\sim 705 \mathrm{Ma}$, of the Matongo carbonatite body itself or, alternatively, of late-stage circulation of fluids originating from it. Emplacement ages spanning over a few tens of million years (between $\sim 748$ and $\sim 705$ Ma for 
the URAPC) are not exceptional for alkaline complexes including carbonatites; see amongst others some African Cenozoic provinces, e.g. Eastern Rift, Virunga, Hoggar, Tibesti.

The $\mathrm{Sr}$ and $\mathrm{Nd}$ isotope compositions provided by the URAPC rocks suggest a cogenetic relation between the carbonatites and the feldspathoidal syenites (Tack et al., 1996). Positive initial $\varepsilon N d$ values $(+0.7$ to +5.2$)$ and low initial ${ }^{86} \mathrm{Sr} /{ }^{87} \mathrm{Sr}$ ratios $(0.7025-0.7030)$ support a mantle-derived origin without evidence for significant assimilation of crustal material (Tack et al., 1984). The inferred source appears to be less depleted in incompatible elements than the typical Depleted Mantle (DM) (Demaiffe, 2008).

\subsection{Syntectonic emplacement}

The URAPC differs from many other alkaline massifs by its relatively large size and elliptic shape (Fig.1A) (Tack et al., 1984; Midende et al., 2014). Boulvais et al. (2015) and Decrée et al. (2015) argue that these properties relate to the syntectonic emplacement of the complex in the overall long-lived extensional tectonic regime associated with the Rodinia breakup (Burke et al., 2003; Hanson, 2003; Tack et al., 1996).

The URAPC was emplaced under NW-SE oriented stretching parallel to the long axis of the elliptic shape. This is consistent with the NW-SE trending regional foliation and the NE-SW oriented shortening. Emplacement was controlled by the development under ductile regime of submeridian large shear zones (Fig. 1B), especially in the eastern part of the inner unit. These shear zones host a vertical foliation that bears a stretching lineation plunging at $\sim 30^{\circ}$ towards the North. Typical C/S structures (described in Decrée et al, 2015) have been recognized along some shear zones, which implies that they were active during magmatic emplacement. Therefore, these shear zones controlled the emplacement of the URAPC from the earliest 
stage of the magmatic differentiation and crystallization through magmatic-hydrothermal transition up to circulations of late-stage hydrothermal fluids.

For example, pegmatoid veins (containing nepheline, sodalite and cancrinite) that correspond to tension gashes in zones of high strain are encountered in deformed zones within the feldspathoidal syenites. A comparable mineral assemblage occurs in mylonitic zones (within the nearby quartz-bearing syenite) as infillings of en échelon sigmoidal tension gashes. These veins and infillings are indicative of fluid circulations during both magmatism and deformation. Some veins display internal deformation, others not.

Brittle deformation at the scale of the URAPC is ubiquitous and superimposed to ductile deformation. It led to rock fracturing (Fig.2B), locally with slickensides and steps on the fractured planes. The rock fragments are cemented by a neoformed phyllosilicate-rich mineral assemblage suggesting that the brittle deformation took place in the shallow crust. The brittle deformation is observed not only in the URAPC but also on a regional scale, e.g. in Western Burundi (adjacent $\sim 1375$ Ma S-type Kayanza granite and (ultra)mafic rocks of the KabangaMusongati alignment; 1205 Ma A-type granites of Central Burundi; Tack et al., 2010) and even more to the West across the Western Rift in the Itombwe Syncline of DRCongo (Fernandez-Alonso et al., 2012). This deformation, which is also accompanied by numerous submeridian faults, is attributed to a far-field effect of the distant East Africa Orogen, located east of the Archaean Tanzania Craton, as a result of the $~ 550$ Ma Gondwana amalgamation (Rosetti et al., 2007; Fernandez-Alonso et al., 2012).

\section{Material and methods}

Fifty-five rock samples of the URAPC have been studied (rock collection Tack, 1977-1982, listed LT "xxx", and field archives, stored at the Royal Museum for Central Africa (RMCA), 
Tervuren, Belgium. In addition, eight samples (listed GPS "xxx") were collected in 2014 during field work carried out in the frame of the digitalization program of the geological map of Burundi (partly funded by the Belgian Development Agency, BTC). All investigated samples are presented in Table 1 and their location reported on Fig.1B. Most analytical data, including mineralogical composition, petrographic texture and geochemistry (major and trace elements) come from two unpublished master theses submitted at Ghent University (Vergauwen, 1990, inner unit of URAPC, and Buysschaert, 1993, outer unit of URAPC). Microprobe data (from these theses) were obtained at the Centre d'Analyse par Microsonde pour les Sciences de la Terre at the Université Catholique de Louvain (Belgium). Major and trace elements analyses (Tables 2-3) were performed at the Geology Department of Ghent University (using atomic absorption spectrometry, AAS) and at the RMCA (using X-ray fluorescence, XRF, and ICP-MS).

To complete the geochemical database (Tables 2-3) additional trace element analyses were carried out on 14 rocks (samples from the RMCA collection and from the field) at the Université Libre de Bruxelles (ULB). For major and trace elements concentration measurements, $\sim 50 \mathrm{mg}$ of powdered samples have been melted by alkaline fusion after adding $0.8 \mathrm{~g}$ of lithium metaborate and $0.2 \mathrm{~g}$ of lithium tetraborate in a graphite crucible. After 10 minutes at $1000{ }^{\circ} \mathrm{C}$, the beads were redissolved in a stirring solution of $\mathrm{HNO}_{3} 5 \%$ plus traces of HF. Major elements were measured on the ThermoScientific ICAP ICP-AES at ULB, using Y as internal standard. Two USGS standards have been used (BHVO-2 and AGV-2) and the total reproducibility was better than $2 \%$ for each element. Loss on ignition was measured on a $0.5 \mathrm{~g}$ aliquot after $5 \mathrm{~h}$ at $800{ }^{\circ} \mathrm{C}$. Trace elements were measured on an Agilent $7700 \mathrm{ICP}-\mathrm{MS}$, also at ULB, by adding In as internal standard. The same USGS standards were used. The total reproducibility was systematically better than $5 \%$. 
For isotopes analyses, performed at ULB, $\sim 200 \mathrm{mg}$ of powdered samples were dissolved by a 3:1 mixture of $\mathrm{HNO}_{3} 14 \mathrm{~N}: \mathrm{HF} 29 \mathrm{~N}$ using high-pressure screwed beakers. After 2 days on a hotplate at $120{ }^{\circ} \mathrm{C}$, the samples were evaporated and redissolved in $\mathrm{HCl} 6 \mathrm{~N}$. After the solutions were clear, several small aliquots were taken for $\mathrm{Sr}$ isotopes, $\mathrm{Rb} / \mathrm{Sr}$ ratio, and $\mathrm{Lu}-\mathrm{Hf}$ and Sm-Nd chronology. Strontium purification was made using Sr.Spec resin in $\mathrm{HNO}_{3}$. Some samples rich in $\mathrm{Rb}$ necessitated a second pass through the resin to ensure a perfect elimination of $\mathrm{Rb}$. The $\mathrm{Rb} / \mathrm{Sr}$ ratio was determined without purification on the Agilent 7700 ICP-MS using a calibration curve of gravimetrically prepared mixed $\mathrm{Rb}$ and $\mathrm{Sr}$ standards. The reproducibility was better than $1 \%$. The Lu-Hf-Sm-Nd cut was spiked with a mixed spike ${ }^{176} \mathrm{Lu}_{-}{ }^{179} \mathrm{Hf}-{ }^{150} \mathrm{Sm}-{ }^{148} \mathrm{Nd}$ (Debaille et al., 2008). After equilibration on a hot plate for $24 \mathrm{~h}$, the purification procedure was the same for both spiked and unspiked samples. In brief, samples were loaded on a cationic column in $1.5 \mathrm{~N} \mathrm{HCl}$. Hafnium was immediately collected, while after rinsing, the REE cut was collected in $6 \mathrm{~N} \mathrm{HCl}$. Neodymium was further purified on a LnSpec column using $0.16 \mathrm{~N}$ and $0.27 \mathrm{~N} \mathrm{HCl}$. For spiked samples, Sm and $\mathrm{Lu}$ were also collected by increasing the strength of $\mathrm{HCl}(0.75 \mathrm{~N}$ and $6 \mathrm{~N} \mathrm{HCl}$ respectively). The $\mathrm{Hf}$ cut was loaded on an anionic column using $6 \mathrm{~N} \mathrm{HCl}$ in order to eliminate $\mathrm{Fe}$. Then the $\mathrm{Hf}$ cut was further purified from Ti by using a Ln-Spec column and a mixture of $6 \mathrm{~N} \mathrm{HCL}$ and $\mathrm{H}_{2} \mathrm{O}_{2}$.

The isotopic compositions of $\mathrm{Sr}, \mathrm{Nd}$ and $\mathrm{Hf}$ were measured on a $\mathrm{Nu}$ Instrument $\mathrm{Nu}$ Plasma 2 multi-collector ICP-MS at ULB. Strontium was measured in wet mode by measuring a standard every 2 samples at $400 \mathrm{ppb}$ in $0.05 \mathrm{HNO}_{3}$. Samples were recalculated with the accepted value of the SRM987 (0.710248, Weis et al., 2006), and the reproducibility was better than $20 \mathrm{ppm}(\mathrm{n}=20)$. For $\mathrm{Nd}$ and $\mathrm{Hf}$, measurements were made using an aridus 2 dessolvator and by measuring a standard every 2 samples at $25 \mathrm{ppb}$ in $0.05 \mathrm{~N} \mathrm{HNO} 3$ and $0.05 \mathrm{~N} \mathrm{HNO}_{3}: 0.05 \mathrm{~N} \mathrm{HF}$ respectively. Samples were respectively recalculated according to the Rennes Nd standard (0.511963, Chauvel and Blichert-Toft, 2001) and the JMC 475 Hf 
standard (0.282163, Blichert-Toft, 2001). The total reproducibility was better than $36 \mathrm{ppm}$ for $\mathrm{Nd}(\mathrm{n}=38)$ and $35 \mathrm{ppm}$ for $\mathrm{Hf}(\mathrm{n}=21)$. Spiked samples were measured on the $\mathrm{Nu}$ Instrument $\mathrm{Nu}$ Plasma 1 at ULB. Spike was deconvoluted according to the procedure described in Debaille et al., 2008.

\section{Petrography and mineral composition}

\subsection{Outer unit}

The rocks of this unit cannot be considered as strictly alkaline since they contain neither alkali amphibole, alkali pyroxene, nor feldspathoids. The dark plutonic rocks, collectively referred to as "gabbro-diorite" (Tack et al., 1984), comprise gabbro, diorite, quartz monzogabbro and monzodiorite. They are predominantly located in the north-western part of the outer unit where they occupy a relative large area (Fig.1A). This contrasts with the situation in the south-eastern part of the URAPC where these rocks have a more limited and scattered distribution. The gabbros contain either olivine (mainly in the NW part) or clinopyroxene (salite) as main dark minerals. Olivine has an intermediate composition $\left(\mathrm{Fo}_{42.9-52.4}\right)$ with orthopyroxene $\left(\mathrm{En}_{54}\right)$ forming sometimes thin reaction rims, locally in association with magnetite. Olivine and clinopyroxene are often surrounded by amphibole (ferro-pargasite or pargasite) and/or biotite (16.09-30.14 \% $\mathrm{FeO}, 6.59-12.99 \% \mathrm{MgO})$, illustrating the discontinuous Bowen series (Figs.3A-B; observed only in the western part of the outer unit). Plagioclase $\left(\mathrm{An}_{38-48}\right)$ occurs as large (up to $3 \mathrm{~mm}$ wide), unzoned or zoned subhedral crystals, frequently saussuritized or albitized. Plagioclase cumulate textures are observed. Alkali feldspar ( $\left.\mathrm{Or}_{88-96} \mathrm{Ab}_{4-12}\right)$, being largely subsidiary, and rare quartz are mainly interstitial components. Zircon, apatite and oxides are primary accessory phases while titanite, epidote and leucoxene are of secondary origin. 
Quartz-bearing syenites constitute the greater part of the outer unit. Textures are hypidiomorphic to panidiomorphic-granular, with large grain size variations (fine-grained to coarsegrained). Major constituents include quartz, perthitic alkali feldspar ( $\mathrm{Or}_{83-67} \mathrm{Ab}_{3-6}$ ), plagioclase $\left(\mathrm{An}_{0.9}\right.$; locally albitized and sericitized), biotite $(26.44-33.87 \% \mathrm{FeO}, 3.02-7.31 \%$ $\mathrm{MgO}$ ), locally transformed into chlorite and amphibole (ferro-edenite) with inclusions of apatite and zircon (Fig.3C). The modal proportions of quartz and plagioclase vary significantly from one outcrop to another. Myrmekitic texture occurs locally. Apatite, zircon, rutile, ilmenite, magnetite, hematite, titanite, epidote and allanite are accessory constituents. Calcite characterizes rocks affected by late alteration.

The granites of Maranga (in the NW part) and Buraniro (in the SE part) are pinkish, mediumto coarse-grained and differ from the quartz-bearing syenites by a lack of amphibole. Quartz, K-feldspar (often perthitic; $\mathrm{Or}_{98} \mathrm{Ab}_{2}$ ), plagioclase $\left(\mathrm{An}_{16}\right)$, clinopyroxene (ferrosalite) and biotite $(30.02 \% \mathrm{FeO}, 3.77 \% \mathrm{MgO})$ are the main constituents. Plagioclase is frequently saussuritized and sericitized. Accessory minerals include apatite (often forming inclusions in biotite), zircon, ilmenite, magnetite, titanite, allanite and hematite. Both granite types have subsolvus affinities and are usually hypidiomorphic-granular textured. However, some Maranga granite samples contain idiomorphic, greyish high-temperature quartz phenocrysts whereas in the Buraniro granite, quartz is xenomorphic and sometimes forms vermicular or wormy intergrowths in K-feldspar.

\subsection{Inner unit}

The silica-undersaturated rocks display various textures and include feldspathoidal syenite (the most abundant rock type) and subordinate feldspathoidal monzonite and ijolite. Most samples are hypidiomorphic-granular textured (Fig.3E) and medium- to coarse-grained, with 
perthitic alkali feldspar $\left(\mathrm{Or}_{93-97} \mathrm{Ab}_{3-7}\right)$, nepheline, sodalite, cancrinite (after nepheline; Fig.3F), biotite, aegirine-augite and amphibole as main constituents. Accessory minerals include garnet (Fig.3G), titanite, fluorite, apatite, zircon and interstitial calcite. Some samples have a medium- to coarse-grained allotriomorphic-granular texture, consist mainly of perthitic alkali feldspar and feldspathoids and contain less mafic constituents. In the southern part of the complex some feldspathoidal syenites have a porphyritic texture with large (up to several cm long) alkali feldspar crystals, nepheline and biotite, in a fine-grained mesostasis made of feldspathoids, alkali feldspar, biotite, pyroxene, amphibole and accessory minerals. Feldspathoidal syenites with a trachytic (fluidal) texture, outlined by subparallel laths of alkali feldspar, are exclusively observed in the eastern part of the inner unit. They show the same mineral assemblage as the other rock types. Some samples display magmatic layering with an alternation of mm-thick bands rich in perthitic alkali feldspar, alkali feldspar associated with nepheline (Fig.3H) and mafic minerals. Pyrochlore and titanite are common (Fig.3H). Clinopyroxene is Fe-rich with an overall aegirine-hedenbergite composition. The composition of garnet - that often forms a reaction rim around clinopyroxene - is $\operatorname{Pyr}_{0} \mathrm{Alm}_{0-3} \mathrm{Gro}_{7-65} \mathrm{And}_{30-}$ 93. Amphibole is taramite whereas biotite displays a large compositional range (16.90-32.84 \% $\mathrm{FeO}, 1.07-10.86 \% \mathrm{MgO})$. Nepheline is the dominant feldspathoid, with low amounts of normative quartz and very low $\mathrm{CaO}$ and $\mathrm{FeO}$ contents $(0.05<\mathrm{CaO}<0.17 \%$, $0.02<\mathrm{FeO}<0.22 \%)$. The composition of nepheline suggests a crystallization temperature below $1068^{\circ} \mathrm{C}$, and even below $700^{\circ} \mathrm{C}$ (empirical geothermometer of Hamilton and McKenzie, 1965). Sodalite and cancrinite, both colourless under the microscope, are secondary phases and alteration products of nepheline and alkali feldspar. In one specific area (west of Kiziba; Fig.1B), both minerals are easily recognized in the hand specimen because of their coarseness and typical colour, respectively intense blue for sodalite and pink-reddish or 
yellow for cancrinite (Fig.2G). In this area, centimetric garnet, associated with minerals of the epidote-clinozoïsite group, has also been observed in one of the outcrops.

\subsection{Carbonatite}

Midende (1984) and Midende et al. (2014) provided a detailed description of the Matongo carbonatite, including a comprehensive petrographical study. A brief summary of the data published by these authors is presented here.

Several facies have been recognized in the Matongo carbonatite. (1) The dominant facies is a fine-grained saccharoidal sövite, comprising mostly calcite (with $0.5<\mathrm{FeO}<3$ wt.\%; $0.1<$ $\mathrm{MgO}<1.6 \mathrm{wt} . \% ; 0.8<\mathrm{SrO}<1.5 \mathrm{wt} . \%$ ) and discrete zones of vanadiferous aegirine (partly transformed into Mg-arfvedsonite) and small grains or prismatic crystals of apatite. Apatite and aegirine locally form cumulates in association with pyrochlore and K-feldspar. Richterite is another mineral phase that may be abundant and constitutes up to $30 \%$ of the sövite rock volume. (2) A coarse-grained sövite made of almost pure calcite $(\mathrm{CaO}$ content close to 55 wt $\%$ ) is found in highly fractured zones of the carbonatite body. At the contact with the host rocks, it may be silicified and Fe-stained. "Late" hydrothermal calcite, slightly enriched in Fe, $\mathrm{Mn}$ and $\mathrm{Mg}$ (up to 1.2 wt.\% $\mathrm{FeO}, 0.7$ wt $\% \mathrm{MgO}$ and 0.6 wt.\% $\mathrm{MnO}$ ), has also been identified in the coarse-grained sövite variety. (3) Ferrocarbonatites form decimeter-wide veins crosscutting the sövites. They consist of fine-grained dolomite and ankerite (13.7-15.4 wt.\% FeO, 11.3-13.7 wt.\% $\mathrm{MgO}, 0.3-0.7$ wt.\% $\mathrm{MnO}$ ), associated with abundant euhedral V-rich magnetite $\left(\mathrm{V}_{2} \mathrm{O}_{3}\right.$ up to 2 wt.\%) and ilmenite crystals.

In addition, two types of fenites occur at the contact with the host metasediments: biotitebearing fenite and K-feldspar-bearing fenite. In the former biotite forms well-developed 
crystals, and is partly converted into phlogopite. Other associated minerals consist of titanite, richterite, calcite and apatite. Both phyllosilicates have in turn been replaced by feldspars (mainly K-feldspar, with accessory albite grains), inducing eventually the formation of $\mathrm{K}$ feldspar-bearing fenite.

The Matongo carbonatite is locally affected by ductile deformation, resulting in the development of a mylonitic foliation. Late fluid circulations have been documented as well (Decrée $e t$ al., 2015).

\section{Whole rock chemistry}

\subsection{Major elements}

A total alkalis versus silica (TAS) diagram (Fig.4A) was used to discriminate the analysed URAPC rocks (Le Maitre et al., 2002). All rocks attributed petrographically to the gabbrodiorite field group plot in the gabbro, diorite, syenodiorite and quartz diorite fields. The quartz-bearing syenites and granites fall in the quartz diorite and granite fields; the feldspathoidal syenites in the nepheline syenite, syenite, syenodiorite and ijolite fields.

Harker diagrams in which the weight percent of eight major and minor elements are plotted against wt.\% silica in abscissa are illustrated in Figs.4B-I (for analytical data, see Table 2). The $\mathrm{SiO}_{2}$ concentrations range from 43.9 to $77.0 \mathrm{wt} . \%$, without any compositional gap. The rocks of the gabbro-diorite group and feldspathoidal syenites have rather low $\mathrm{SiO}_{2}$ contents, 43.9-59.0\% and 47.5-62.1\%, respectively.

Two differentiation trends can be distinguished: 1) one for the silica-saturated rocks, compositionally varying from gabbro-diorite, through quartz-bearing syenite to granite; and 2) another for the silica-undersaturated rocks, including feldspathoidal syenites s.s., feldspathoidal monzonite and ijolite. However, the overall evolutions are similar for both 
series: the $\mathrm{MgO}, \mathrm{Fe}_{2} \mathrm{O}_{3}, \mathrm{CaO}, \mathrm{TiO}_{2}$ and $\mathrm{P}_{2} \mathrm{O}_{5}$ contents decrease more or less regularly with increasing $\mathrm{SiO}_{2}$ (Figs. 4B, 4C, 4G, 4H and 4I), while the $\mathrm{K}_{2} \mathrm{O}$ contents increase (Fig.4F). The $\mathrm{Al}_{2} \mathrm{O}_{3}$ and $\mathrm{Na}_{2} \mathrm{O}$ contents first increase slightly (Figs.4D-E) and then decrease when the $\mathrm{SiO}_{2}$ content reaches 55 to 60 wt.\%. It is worth mentioning that the $\mathrm{Na}_{2} \mathrm{O}$ content of the feldpathoidal syenite is significantly higher than those of the silica-saturated rocks, resulting in a very distinctive trend.

The Maranga granite (NW part of the outer unit) appears to be richer in silica (mean $=75.6$ wt.\%) than the Buraniro granite (SE part of the outer unit) (mean $=71.6 \mathrm{wt} . \%$ ), and there is no overlap. In addition, the studied Maranga granite samples are characterized by higher $\mathrm{Na}_{2} \mathrm{O}$ contents (> than $\left.6 \mathrm{wt} . \%\right)$ than those belonging to the Buraniro granite do $(<5 \mathrm{wt} . \%)$.

\subsection{Trace elements}

Rocks of the gabbro-diorite group have moderate REE contents, with $\Sigma$ REE ranging from 137 to $371 \mathrm{ppm}$ (Table 3). Their chondrite-normalized REE patterns (Fig.5A) show $\mathrm{La}_{\mathrm{N}}$ values ranging from 28 to 193. The LREE enrichment is moderate $\left(\mathrm{La}_{N} / \mathrm{Yb}_{\mathrm{N}}\right.$ ratios ranging from 9.6 to 20), with generally positive $\mathrm{Eu}$ anomalies (Eu/Eu* ratios up to 2.4 ), except for a few samples that present slightly negative anomalies (Eu/Eu* down to 0.73). Sample LT95, collected at the contact with a feldspathoidal syenite dyke, displays a particular trend with $\sum \mathrm{REE}=67$ and $\mathrm{La}_{\mathrm{N}} / \mathrm{Yb}_{\mathrm{N}}=2.4$, which probably results from alteration as suggested by the high $\mathrm{Na}_{2} \mathrm{O} / \mathrm{K}_{2} \mathrm{O}$ value $(>8$ ) of the rock. Quartz-bearing syenites are more enriched in REE than the rocks of the gabbro-diorite group (Fig.5B), with values ranging from 308 to 6978 ppm (Table 4). They have $\mathrm{La}_{N} / \mathrm{Yb}_{\mathrm{N}}$ ratios going from 9.8 to 48 and more pronounced negative $\mathrm{Eu}$ anomalies $\left(0.26<\mathrm{Eu} / \mathrm{Eu}^{*}<0.90\right.$; Table 4). Sample GPS36, which is strongly albitized, differs considerably from the others in having a less enriched REE pattern and a strong positive Eu 
anomaly $\left(\mathrm{Eu} / \mathrm{Eu}^{*}=2.09\right)$. The granites are characterized by moderately fractionated patterns $\left(1.7<\mathrm{La}_{\mathrm{N}} / \mathrm{Yb}_{\mathrm{N}}<18\right.$; Fig. 5C), lower REE contents $(102<\Sigma \mathrm{REE}<671)$ and similar to deeper negative $\mathrm{Eu}$ anomalies. The feldspathoidal syenites are also moderately enriched in REE, with $\Sigma$ REE varying from 102 to 588 ppm (Table 3), but they appear to be more fractionated $(6.8<$ $\left.\mathrm{La}_{N} / \mathrm{Yb}_{\mathrm{N}}<55\right)$ than the saturated rocks (Fig.5D), with $\mathrm{La}_{N} / \mathrm{Yb}_{\mathrm{N}}$ ratios ranging from 7 to 55 exhibiting variable negative Eu anomalies $\left(0.24<\mathrm{Eu} / \mathrm{Eu}^{*}<1\right)$. The $\mathrm{Eu}$ anomaly is overall correlated to the $\mathrm{SiO}_{2}$ content (Fig.4J). Regarding the rocks of the gabbro-diorite group and the quartz-bearing syenites, the variation diagram shows an overall increase of the $\Sigma$ REE content versus $\mathrm{SiO}_{2}$, and for the granites a decrease of the $\Sigma$ REE yersus $\mathrm{SiO}_{2}$ (Fig.4K).

Finally, there is no significant difference between the evolution displayed by samples from the NW and SE parts of the outer unit. Primitive mantle-normalized spidergram patterns (Fig.5E-5H) show that most URAPC rocks share common characteristics: (1) an overall enrichment compared to the primitive mantle, both in large-ion lithophile (LILE), i.e. $R b_{N}$ values from 9 to 534, and in high-field-strength elements (HFSE), i.e. $\mathrm{Nb}_{\mathrm{N}}$ values from 6 to 545; (2) common and strong negative $\mathrm{Sr}, \mathrm{Ba}, \mathrm{P}$, and $\mathrm{Ti}$ anomalies. These anomalies are less pronounced than in rocks of the gabbro-diorite group. Abnormal patterns were recorded for the altered samples LT95 and GPS36.

\section{Isotope geochemistry}

The $\mathrm{Sr}, \mathrm{Nd}$ and $\mathrm{Hf}$ isotopic compositions of the URAPC rocks are listed in Table 4. The initial isotopic ratios have been calculated on the basis of an emplacement age of $\sim 705 \mathrm{Ma}$ (Midende et al., 2014). The initial ${ }^{87} \mathrm{Sr} /{ }^{86} \mathrm{Sr}$ ratios vary considerably, - from 0.7040 to 0.7077 - for rocks of the gabbro-diorite group, from 0.7077 to 0.7096 for quartz-bearing syenites, from 0.7088 to 0.7214 for granites, and from 0.7031 to 0.7090 for feldspathoidal syenites. Three samples 
(quartz-bearing syenite LT693, and the granites LT929 and LT 977) show abnormally low initial ${ }^{87} \mathrm{Sr} /{ }^{86} \mathrm{Sr}$ ratios $(<0.700)$. The two granites are significantly enriched in $\mathrm{Rb}(>300$ $\mathrm{ppm}$ ). Their $\mathrm{Rb} / \mathrm{Sr}$ isotopic system has obviously been disturbed (open-system behaviour, with possible addition of $\mathrm{Rb}$, with other alkalis by late-stage fluids). These data are therefore not plotted on Figs.6 and 7 and will not further be discussed here.

The Nd isotopic compositions of the URAPC rocks also vary a lot. The initial $\varepsilon N d$ values span a fairly large range of values, from positive to negative. The gabbro-diorite group, the quartz-bearing syenites and the granites display largely overlapping ranges: from +3.2 to -5.7 , from +2.2 to -4.6 and from +2.2 to -4.4 , respectively. The feldspathoidal syenites yielded less scattered values, most values ranging from +1.5 to -2.2 .

The new data are consistent with the isotopic data of Tack et al. (1984), which are also mentioned in Table 4 and on Fig.6A. In the Nd-Sr isotopic diagram (Fig. 6A), most samples including the Matongo carbonatites $\left(0.7028<{ }^{87} \mathrm{Sr} /{ }^{86} \mathrm{Sr}<0.7040,+5.2<\varepsilon \mathrm{Nd}_{(\mathrm{i})}<+0.2\right.$; Demaiffe, 2008) - plot more or less along a mixing hyperbola (the dashed orange line on Fig. 6A). The carbonatites, with the lowest $\mathrm{Sr}$ initial composition and the most positive $\varepsilon N d$ values, represent the end-member. The Sr isotopic compositions of some saturated and undersaturated samples are shifted to the right of the hyperbola (the dashed blue lines on Fig.6A).

The initial $\varepsilon H f$ of the URAPC samples also vary substantially. The dispersion of the data and the lack of correlation can be seen in a $\varepsilon \mathrm{Hf}_{(\mathrm{i})}$ vs. $\varepsilon \mathrm{Nd}_{(\mathrm{i})}$ diagram (Fig.6B). The gabbro-diorite group shows $\varepsilon \mathrm{Hf}_{(\mathrm{i})}$ values ranging from 9.2 to -5.8 . The quartz-bearing syenites and the granites yielded $\varepsilon \mathrm{Hf}_{(\mathrm{i})}$ values varying from 3.1 to -12.2 and from 0.7 to -10.2 , respectively. The feldspathoidal syenites finally yielded $\varepsilon \mathrm{Hf}_{(\mathrm{i})}$ values going from -10.7 to 6.1. 


\section{Discussion}

\subsection{Fractional crystallization}

It is evident that the saturated and undersaturated series are distinct in most of the variation diagrams (Fig. 4), and that both series fractionate independently of each other. However, the shapes of the geochemical evolution trends revealed by the major, minor and trace element data of these series (Figs.4, B-I) are overall comparable. The decrease of the $\mathrm{MgO}, \mathrm{Fe}_{2} \mathrm{O}_{3 \text { tot }}$, $\mathrm{CaO}$ and $\mathrm{TiO}_{2}$ contents with increasing $\mathrm{SiO}_{2}$ contents (Figs.4B,C,G and $\mathrm{H}$ ) recorded in rocks of the gabbro-diorite group is likely to result from fractionation of mafic phases, olivine first, followed by clinopyroxene, amphibole, biotite and oxides. The decrease of the $\mathrm{P}_{2} \mathrm{O}_{5}$ content (Fig.4I) with increasing silica is to be linked with apatite fractionation.

The bell-shaped evolution of the $\mathrm{Na}_{2} \mathrm{O}$ content (Fig.4E) and to a lesser extent of the $\mathrm{K}_{2} \mathrm{O}$ content (Fig.4F) with increasing silica content suggests early fractionation of calcic plagioclase followed, at an intermediate stage of evolution, by fractionation of alkali feldspar (and biotite). Regarding the undersaturated series, nepheline crystallized together with alkali feldspar during the final stages, still with a notably higher $\mathrm{Na}_{2} \mathrm{O}$ content compared to the saturated rocks for a given $\mathrm{SiO}_{2}$ content.

The marked negative anomalies of $\mathrm{Sr}, \mathrm{Ba}, \mathrm{Ti}$ and $\mathrm{P}$ in the quartz-bearing syenites, the granites and the feldpathoidal syenites are consistent with fractionation of plagioclase, alkali feldspar, Fe-Ti oxides and apatite (Figs.5F-H). The deepening of the Eu anomaly (from $\sim 0.8$ to $\sim 0.1$ ) in the quartz-bearing syenites and the granites with increasing $\mathrm{SiO}_{2}$ content (Fig.4J) points to the continuous fractionation of plagioclase in the saturated series.

As to the saturated series, the bell-shaped evolution of the $\Sigma$ REE content with increasing $\mathrm{SiO}_{2}$ content (Fig.4K) suggests that the REEs behave as incompatible elements during the early stages of the magmatic evolution and as compatible elements at an intermediate stage (at 
about $65 \% \mathrm{SiO}_{2}$ ). Regarding the quartz-bearing syenites - the most REE-enriched rocks positive correlations between the $\mathrm{La}_{\mathrm{N}} / \mathrm{Yb}_{\mathrm{N}}$ ratios and the total REE content (Fig.4L), and between $\Sigma$ REE and $\mathrm{P}_{2} \mathrm{O}_{5}$ contents (Fig.4M) are indicative of fractionation of LREE-enriched phosphates such as apatite and/or monazite. However, the fractionation of other REEminerals, allanite e.g. (also strongly enriched in LREE; Gieré and Sorensen, 2004), cannot be ruled out.

\subsection{Assimilation/contamination processes and coexistence of saturated and unsaturated} series

In the $\varepsilon \mathrm{Nd}_{(\mathrm{i})} \mathrm{vs} .{ }^{87} \mathrm{Sr}^{86}{ }^{8 \mathrm{Sr}_{(\mathrm{i})}}$ diagram, the URAPC samples roughly plot along a hyperbolic trend (the dashed orange line on Fig.6A). The two end-members correspond, on one hand, to the Matongo carbonatite (with the most positive $\varepsilon \mathrm{Nd}_{(\mathrm{i})}$ values and the least radiogenic $\mathrm{Sr}$ isotopic ratios, Demaiffe, 2008), which are largely overlapping with the feldspathoidal syenites and, on the other hand, to a crustal component (negative $\varepsilon \mathrm{Nd}_{(\mathrm{i})}$ values and radiogenic Sr ratios). The ${ }^{87} \mathrm{Sr} /{ }^{86} \mathrm{Sr}$ initial ratios increase generally with increasing $\mathrm{SiO}_{2}$ content (Fig.7A); moreover, these ratios are roughly linearly correlated with $1 / \mathrm{Sr}$ (Fig.7B), pointing to a progressive contamination in the course of the fractionation process (AFC process). This contamination trend is not clearly seen in the $\varepsilon \mathrm{Nd}_{(\mathrm{i})}$ vs. $\varepsilon \mathrm{Hf}_{(\mathrm{i})}$ diagram (Fig.6B), where the Hf isotopic composition shows a large vertical variation compared to the $\mathrm{Nd}$ isotopic composition. Large variations in radiogenic $\varepsilon \mathrm{Hf}$ is common in cratonic domains, as the Lu-Hf system is very sensitive to long-term complex depletion of the lithospheric root (e.g. Pivin et al., 2013). On the other hand, as Lu and Hf are not hosted in the same mineral phases (contrary to the two rare earths $\mathrm{Sm}$ and $\mathrm{Nd}$ that behave more coherently), it cannot be excluded that the lack of correlation in the $\varepsilon \mathrm{Nd}_{(\mathrm{i})}{\mathrm{vs} . \varepsilon \mathrm{Hf}_{(\mathrm{i})}}$ diagram actually reflects secondary processes, as discussed in paragraph 7.3. 
Besides the general hyperbolic trend in the $\varepsilon \mathrm{Nd}_{(\mathrm{i})}$ vs. ${ }^{87} \mathrm{Sr} /{ }^{86} \mathrm{Sr}_{(\mathrm{i})}$ diagram, some samples (whatever their mineralogical composition) plot distinctly to the right of the trend toward high ${ }^{87} \mathrm{Sr} /{ }^{86} \mathrm{Sr}$ values (the dashed horizontal blue lines on Fig.6A). This may result from late stage/hydrothermal processes that affected the URAPC (see section 7.3 below).

The country rocks of the URAPC are potential contaminants in case of upper crustal contamination/assimilation. Deeper crustal rocks of the Archaean Tanzanian Craton can also be invoked if, during the magma ascent, contamination started in the deep crust. The country rocks of the Karagwe-Ankole Belt, compositionally comparable to the rocks of the Kibara Belt (Fernandez-Alonso et al., 2012), define a very large domain with typical crustal signature (recalculated at $705 \mathrm{Ma}:{ }^{143} \mathrm{Nd} /{ }^{144} \mathrm{Nd}<0.5113,{ }^{87} \mathrm{Sr} /{ }^{86} \mathrm{Sr}>0.710$; Fig.8A).

There is no systematic and/or regular increase of the contamination rates, neither towards the outer part of the URAPC, nor in the vicinity of the large shear zones that played a crucial role in the emplacement of the URAPC (Boulvais et al., 2015; Decrée et al., 2015). Therefore, it seems unlikely that contamination by/or assimilation of country rocks has taken place during emplacement at high crustal level. Most probably it occurred during magma ascent or in (a) intermediate magma chamber(s).

Several alkaline plutonic complexes occurring along the Western Rift contain both saturated and undersaturated rocks (Tack et al., 1984, 1996), as it is observed worldwide (Platt, 1996). Combination of assimilation and fractional crystallization (AFC process) is invoked by some authors (e.g., Chen et al., 1994; Harris et al., 1999; Landoll et al., 1994; Xu et al., 2016; Zhu et al., 2016) to explain the coexistence of both series. Other authors (e.g., Beccaluva et al., 2017; Eby, 1985), however, take for granted the existence of two different sources (parental magmas). 
In the URAPC, the rocks of the saturated series display more radiogenic $\mathrm{Sr}$ isotope compositions and more negative $\varepsilon \mathrm{Nd}(\mathrm{i})$ values than the undersaturated series. This argues for a larger degree of contamination for the saturated rocks and is consistent with AFC processes.

There is field evidence (Tack et al., 1984) that the saturated rocks of the outer unit were emplaced before the undersaturated rocks of the inner unit (e.g., xenoliths deriving from the outer unit occur in the inner unit, whereas numerous dykes of feldspathoidal syenite intrude the outer unit), the latter followed by the Matongo carbonatite. Assuming that assimilation/contamination has taken place during magma ascent or in intermediate magma chambers (see above), crystallization of the contaminated magma close to the wall of the plumbing system could have limited the interaction between the primary undersaturated magma (tapped from the underlying parental magma chamber) and the country rocks. This would then lead to emplacement of successive magma pulses with decreasing crustal contamination, in line with the saturated series significantly more contaminated than the undersaturated series. Such armouring of the plumbing system, inducing a decrease of crustal contamination with time, is in line with the subvertical concentric magmatic layering observed in the feldspathoidal syenites of the N-S trending internal unit (Tack et al., 1984). Such a mechanism has also been proposed for the Messum igneous complex in Namibia (Harris et al., 1999) and the Kangerlussuaq complex in East Greenland (Riishuus et al., 2006).

In conclusion, the new data strongly suggest that the saturated and the undersatured series are cogenetic: (i) they are spatially and temporally (respectively 748 and $739 \mathrm{Ma}$ ) associated. Long-lived alkaline complexes $(\sim 15 \mathrm{Ma})$ have been documented in East Greenland (Kangerlussuaq complex; Riishuus et al., 2006) and southern Brazil (Lages complex; Morbidelli et al., 2000); and (ii) they originate from the same source (see section 7.5 below), even if the alkalinity and the silica content of the parental magma have been modified during 
the magmatic evolution of the complex by armouring of the plumbing system and crustal assimilation/contamination.

\subsection{Late contamination/alteration of the URAPC rocks}

The three units of the URAPC were emplaced syntectonically in shear-zones recognized to be the main plumbing system for late-magmatic/metasomatic/hydrothermal fluids (Decrée et al., 2015). The circulation of fluids at the scale of the whole URAPC induced the mobilization and redistribution of many elements, including HFSEs and REEs (Decrée et al., 2015) and resulted at the end in abnormal concentrations (either enrichment or depletion) of certain elements. This may explain the particular outlook of the REE patterns and spidergrams of the strongly albitized quartz-bearing syenite GPS36 (Figs.5, B and F) and gabbro LT95 (Figs.5, A and E), which were altered at the contact with a syenite dyke. This could also be related to the lack of correlation in the diagram $\varepsilon N d(i)$ vs.eHf(i) (Fig.6B) as phosphate will be more prone to disturbance in Lu-Hf than in Sm-Nd (Debaille et al., 2017). Late fluids may also have induced significant changes in the initial $\mathrm{Sr}$ isotope composition of the rocks of the URAPC due to interaction with altered country rocks, at different times and for the different rocks of the complex.

In the $\mathrm{Nd}-\mathrm{Sr}$ isotope diagrams (Figs.6A and 8A), some samples plot to the right of the hyperbolic mixing curve, along roughly horizontal lines (the blue dashed on the figures), e.g. the strongly albitized quartz-bearing syenite GPS36 (which contains calcite grains and veinlets) and the granite LT1011. A shift of the primary Sr isotopic signature (with minor or no influence on the Nd system) can be attributed to syn- or late-fluid interaction with the rocks during emplacement (by addition of radiogenic $\mathrm{Sr}$ ), as it is also known to occur in other complexes (Chen et al.,1994; Landoll et al.,1994). 


\subsection{The Matongo carbonatite: the final pulse of the URAPC}

The Sr-Nd-Hf isotope data strongly suggest that the rocks of the undersaturated inner unit, the Matongo carbonatite and the rocks composing the saturated outer unit are cogenetic. Similar conclusions have been proposed for other alkaline provinces, e.g. the Grønnedal-Ika complex in Greenland (Halama et al., 2005) and several complexes of the Kola Peninsula (Downes et al., 2005) (see also Bell, 1998). However, the origin and the coexistence of such magmas is still a matter of debate. It is commonly assumed that carbonatite could result either from the separation by immiscibility of the carbonatitic melt from a carbonated silicate melt (at crustal pressures below 1 Gpa) (e.g., Freestone and Hamilton, 1980; Kjarsgaard, 1998), or by intensive crystal fractionation of a similar parental magma (e.g., Doroshkevich et al., 2017; Kjarsgaard, 1998; Lee and Wyllie, 1994; Verhulst et al., 2000). Alternatively, silicate and carbonated magmas could likely be produced by distinct melting events (e.g., Harmer and Gittins, 1998).

However, the hypothesis of a carbonatitic magma evolving from an undersaturated silicate magma is largely favoured (e.g., Beccaluva et al., 1992; Bodeving et al., 2017; Guzmics et $a l ., 2015)$ and is also adopted for the URAPC. The relatively high $\mathrm{Nb}$ and $\mathrm{Zr}$ contents of the feldspathoidal syenites of the inner unit (52-368 ppm $\mathrm{Nb}$ and 111-744 ppm $\mathrm{Zr}$ ) as compared to those of the Matongo carbonatite (1-168 ppm Nb and 11-339 ppm Zr; Midende et al., 2014; Fig. $5 \mathrm{H})$ argue for an origin of the carbonatite by immiscibility. These elements are indeed expected to strongly partition into the silicate melts as shown by experimental studies between immiscible carbonate and silicate liquids (Martin et al., 2012; Veksler et al., 2012).

In the URAPC, the carbonatite has been emplaced after the two associated silicate magmas (the saturated and the undersaturated rocks) but spatially and genetically belongs to the 
URAPC. This is easily explained because (i) in many alkaline complexes silicate and carbonated magmas use the same plumbing system (e.g., Bell et al., 1998; Harmer, 1999; Woolley and Kjarsgaard, 2008), and (ii) a carbonated melt has a higher melt-solid interfacial energy than the coexisting silicate melt, which restricts its mobility independently of the silicate melt. As a result, melt separation can be achieved only when the silicate melt has solidified: this however remains questionable considering the large time gap, 30 Ma between the emplacement of the feldspathoidal syenite and the carbonatite (note however that state-tothe-art dating would help specifying this time gap), or within liquid-dominated reservoirs, such as sills, dykes or subsurface chambers (Minarik, 1998).

\subsection{Sources of the URAPC magma(s)}

To determine the nature of the source of the URAPC primary magma (or magmas), only data provided by uncontaminated (or slightly contaminated) samples have been used. The latter include the Matongo carbonatite and, to a lesser extent, the undersaturated feldpathoidal syenites. The ranges of the initial $\mathrm{Sr}, \mathrm{Nd}$ and $\mathrm{Hf}$ isotope compositions of these rocks are respectively $\quad 0.7029<{ }^{87} \mathrm{Sr} /{ }^{86} \mathrm{Sr}_{(\mathrm{i})}<0.7036 ; \quad+4.6<\varepsilon \mathrm{Nd}_{(\mathrm{i})}<+0.2 \quad$ (Demaiffe, 2008) and $0.7031<{ }^{87} \mathrm{Sr}^{86} \mathrm{Sr}_{(\mathrm{i})}<0.7056 ;+1.5<\varepsilon \mathrm{Ed}_{(\mathrm{i})}<-2.2 ;+0.1<\varepsilon \mathrm{Hf}_{(\mathrm{i})}<-5.2 . \quad$ In agreement with Demaiffe (2008) and Midende et al. (2014), these isotopic data attest for the role of an asthenospheric mantle source less depleted than the depleted mantle (DM) and possibly contaminated by the subcontinental lithospheric mantle (SCLM).

In the $\varepsilon \mathrm{Hf}_{(\mathrm{i})}-\varepsilon \mathrm{Nd}_{(\mathrm{i})}$ diagram (Fig.8B), almost all the samples plot in the field of the Mantle Array, with most of them falling in the field of the modern OIB, thus emphasizing involvement of the asthenospheric mantle. There is however a dispersion of the data points towards the field of the crust on one hand and towards less radiogenic $\varepsilon \mathrm{Hf}_{(\mathrm{i})}$ compositions (- 
$\left.12.2<\varepsilon \mathrm{Hf}_{(\mathrm{i})}<-5.4\right)$ on the other hand. The URAPC data thus falls in the large field of the Kaapvaal craton xenoliths (Simon et al, 2007). This large field reflects the geochemical (and thus the isotopic) heterogeneity of this mantle domain which results from its long and complex history with several melting and metasomatic enrichment episodes (Simon et al, 2007). The contribution of an old SCLM component could explain the rather wide distribution of the URAPC rocks in the Nd-Hf diagram (Figure 8B), and the lack of correlation between $\varepsilon \mathrm{Nd}_{(\mathrm{i})}$ and $\varepsilon \mathrm{Hf}_{(\mathrm{i})}$ compositions. An SCLM source is consistent with the observed trace elements (LREE, LILE and HFSE) enrichment of the URAPC rocks. A contamination of the mantle-derived magmas with crustal material is also attested.

Enriched SCLM is a common source for alkaline complexes (e.g., Harmer and Gittins, 1998; Miyazaki et al., 2003), in combination or not with plume involvement (e.g., Tappe et al., 2007; Roulleau and Stevenson, 2013; Saha et al., 2017; Chandra et al., 2018). The involvement of a plume has in particular been mentioned to explain the emplacement of temporally and spatially associated alkaline complexes and flood basalts in the western branch of the East African Rift (Bell, 2001; Ernst and Buchen, 2003), as a superplume could be present under Rodinia ( $\mathrm{Li}$ et al., 2008). However, its role in the genesis of the alkaline URAPC remains uncertain (Midende et al., 2014).

\subsection{Differentiation and late-stage circulations of fluids with respect to geometry of the}

\section{URAPC}

In the outer unit of the URAPC, the NW and SE parts can be spatially distinguished by several features: (i) the size of the area of exposure of the gabbro-diorite field group (see 4.1), (ii) the more evolved nature of the Maranga granite, in the NW, compared to the Buraniro granite, in the $\mathrm{SE}$ (Fig.3E), in combination with a significantly higher $\mathrm{Na}_{2} \mathrm{O}$ content $(>6 \mathrm{wt}$ $\%$ and $<5$ wt $\%$, respectively); (iii) the habit of the quartz crystals included of both granites: 
idiomorphic (Maranga) vs. xenomorphic (Buraniro) (see 4.1.). The distinct magmatic evolution of the two parts of the outer unit is even more evidenced by the occurrence - inbetween these two parts - of the inner unit of feldspathoidal syenite itself bordered to the East by several large shear zones (Fig.1B). In the NW part of the outer unit, the gabbro-diorite group is located to the North and the Maranga granite to the South with the quartz-bearing syenites in-between. This suggests that the most evolved rocks are encountered towards the south and, at the same time, it points to the fact that the rocks of the gabbro-diorite group corresponds to a deeper and the Maranga granite to a more apical portion of the intrusion.

In the southern portion of the inner unit, enrichment of the feldspathoidal syenites in sodalite and cancrinite (both with pronounced colours) as well as in garnet and associated clinozoisitepyrochlore (Fig. 1B), is indicative of a local increase of fluid circulation during the magmatic evolution. The southern portion thus likely also corresponds to a more apical part of the intrusion. This is in agreement with the previously proposed setting for the western part of the outer unit.

In the URAPC, most of the late-magmatic/metasomatic/hydrothermal activity is thus recorded along submeridian shear zones affecting the eastern border of the inner unit (see 7.3.; Fig.1B) and, more to the ENE, in dykes of feldspathoidal syenite with blue sodalite crystals forming part of the outer unit. This large corridor of shear zones has been the locus of fluid circulations during 1) the late-stage evolution of the emplacement of the undersatured magma, and 2) the diversified late-stage activity postdating the emplacement of the carbonatite (see 7.3.). Crustal-scale shear zones thus played a prominent role during the emplacement of the URAPC, controlling the pattern of magmatic differentiation of the complex and - even more important - channeling successive late-stage circulations of hydrothermal fluids. 


\subsection{The URAPC in the context of the other alkaline complexes along the Western Rift}

The magmatic evolution proposed for the URAPC is similar to what happened in many other alkaline complexes (e.g., Beccaluva et al., 1992; Chen et al., 1994; Landoll et al., 1994). Nevertheless, the URAPC differs from numerous alkaline-carbonatite complexes by its syntectonic way of emplacement, elongate shape and large size $(\sim 24 \mathrm{~km}$ long and $\sim 10 \mathrm{~km}$ wide).

Other elongate Neoproterozoic complexes exposed along the present-day western branch of the EAR occur south-east of the URAPC, in Tanzania, e.g : 1) Sangu-Ikola (18.3 x $1.6 \mathrm{~km})$; 2) Mbozi (32.2 x 1.6 to $12.9 \mathrm{~km})$ and 3) Nachendezwaya $(2.4 \times 0.8 \mathrm{~km})$ (see location and references in Tack et al., 1984; Fig.11; Table 5). Although their structural setting versus magmatism has not been studied recently, it was previously recognized, e.g. for the SanguIkola complex, that "the tectonic structure predates the carbonatite and controlled the emplacement". Alternatively, to the $\mathrm{N}$ of the URAPC, the complexes display the more "normal", subcircular geometry and have a smaller size, e.g. 1) Bingo-Mont Home (6 x 4.5 $\mathrm{km})$; 2) Lueshe $(3.1 \times 2.1 \mathrm{~km})$ and 3) Kahuzi $(9 \times 7 \mathrm{~km})$. As to the south-eastern group of complexes, with "structural control" during emplacement, a link can be suggested with the peculiar geologic setting of the region corresponding to the NW-SE trending Ubende Shear belt $(2.1 \mathrm{Ga})$, which experienced repeatedly reactivation, amongst others, during the Mesoproterozoic, Neoproterozoic, Karoo and Cenozoic (Klerkx et al., 1998; Delvaux et al., 2012). However, the discussion of the differences between both groups of complexes is outside the scope of this paper.

\section{Conclusion}


The Neoproterozoic Upper Ruvubu Alkaline Plutonic Complex (URAPC) in Burundi consists of three main units: an outer unit with silica-saturated plutonic rocks, an inner unit with silicaundersaturated plutonic rocks, and a carbonatite, each with a specific emplacement age and petrological composition.

This petrological, geochemical and radiogenic ( $\mathrm{Sr}, \mathrm{Nd}$ and $\mathrm{Hf}$ ) isotope study focuses on the processes that lead to the formation of the URAPC: (1) Fractional crystallization is evidenced by the chemical evolution trends emanating from the major, minor and trace element data, and from clear $\mathrm{P}, \mathrm{Ti}$ and $\mathrm{Ba}$ anomalies appearing in the trace element patterns; (2) crustal assimilation/contamination is suggested by the large range of $\mathrm{Nd}$ isotope compositions characterizing the analysed rocks, and the general increase of the $\mathrm{Sr}$ isotope ratio with increasing $\mathrm{SiO}_{2}$ contents, and finally (3) late-magmatic/hydrothermal alteration is consistent with the increase of the $\mathrm{Sr}$ isotope composition of the samples without changing significantly their $\mathrm{Nd}$ isotope composition.

The two silicate magmatic series of the URAPC (an undersaturated one with minor carbonatite and a saturated one) appear to be cogenetic. The source of the magma(s) could be an old SCLM. The series constituting the outer unit is more contaminated than the inner, undersaturated series. The carbonatite could have evolved by liquid immiscibility.

Unlike many alkaline-carbonatite complexes, the URAPC is rather large-sized. It was emplaced syntectonically under extensional regime. Several structural levels have been identified in its western part: the north-western part of the outer unit, where gabbros predominate, would correspond to a deep zone whilst the granites outcropping in the southeastern part would correspond to apical zones. The new data provide keys of critical importance for a better understanding of the magmatic differentiation history and late-stage circulations of fluids of alkaline massifs in general. 


\section{Acknowledgments}

Field work was carried out in 2014 and was partly funded by a program of the Belgian Development Agency (BTC) dedicated to digitalization of the geological map of Burundi. The authors would like to express their gratitude to the RMCA (Tervuren) for access to the studied rock samples and they also thank the University of Burundi for assistance in organizing the field campaign. VD thanks the FRS-FNRS and ERC StG ISoSyC for funding.

The authors are also grateful to Victoria Pease (Editor), Kathryn Goodenough (Reviewer) and an anonymous reviewer, for helpful remarks on the manuscript. Their comments have contributed to improve substantially the quality of this paper.

\section{References}

Beccaluva L., Barbieri, M., Born, H., et al., 1992. Fractional crystallization and liquid immiscibility processes in the alkaline-carbonatite complex of Juquiá (São Paulo, Brazil). Journal of Petrology 33, 1371-1404.

Beccaluva, L., Bianchini, G., Natali, C., Siena, F., 2017. The alkaline-carbonatite complex of Jacupiranga (Brazil): Magma genesis and mode of emplacement. Gondwana Research 44, 157-177.

Bell, K., 1998. Radiogenic isotope constraints on relationships between carbonatites and associated silicate rocks - a brief review. Journal of Petrology 39, 1987-1996.

Bell, K., Kjarsgaard, B.A., Simonetti, A., 1998. Carbonatites - into the twenty-first century. Journal of Petrology 39, $1839-1845$.

Bell, K., 2001. Carbonatites: relationships to mantle-plume activity, in: Ernst, R.E., Buchan, K.L. (Eds.), Mantle Plumes: Their Identification Through Time, GSA Spec. Pap. 352, pp. 267-90.

Black, R., Lameyre, J., Bonin, B., 1985. The structural setting of alkaline complexes. Journal of African Earth Sciences 3, 5-16. 
Blichert-Toft, J., 2001. On the Lu-Hf isotope geochemistry of silicate rocks, Geostandards Newsletter 25, 41-56.

Bodeving, S., Williams-Jones, A.E., Swinden, S., 2017. Carbonate-silicate melt immiscibility, REE mineralising fluids, and the evolution of the Lofdal Intrusive Suite, Namibia. Lithos 268-271, 383-398.

Boulvais, P., Cobert, C., Baele, J.-M., Tack, L., Nimpagaritse, G., Midende, G., Gardien, V., Demaiffe, D., Decrée, S., 2015. A syntectonic alkaline massif in Burundi: geology, fluid-rock interaction and element (REE, HFSE) mobility. 13th SGA Biennial meeting, Nancy (France), Abstract book, 993-996.

Burke, E.A.J., 1998. New data on zircon from Matongo (Burundi). Aardkundige Mededelingen 9, 17-20.

Burke, K., Ashwal, L.D., Webb, S.J., 2003. New way to map old sutures using deformed alkaline rocks and carbonatites. Geology 31, 391-394.

Buysschaert, X., 1993. Mineralogisch en geochemisch onderzoek van de buitenste eenheid van het alkalisch plutonisch complex van de Hoge-Ruvubu (Burundi). MSc thesis, University of Gent, Belgium, $121 \mathrm{p}$.

Chandra, J., Paul, D., Viladkar, S. G., Sensarma, S., 2018. Origin of the Amba Dongar carbonatite complex, India and its possible linkage with the Deccan Large Igneous Province. Geological Society, London, Special Publications 463, 137-169.

Chauvel, C., Blichert-Toft, J., 2001. A hafnium isotope and trace element perspective on melting of the depleted mantle, Earth and Planetary Science Letters 190, 137-151.

Chen, J., Henderson, C.M.B., Foland, K.A., 1994. Open-system, sub-volcanic magmatic evolution: Constraints on the petrogenesis of the Mount Brome Alkaline Complex, Canada. Journal of Petrology 35, 11271153.

Debaille, V., Yin, Q.-Z., Brandon, A., Jacobsen, B., 2008. Martian mantle mineralogy investigated by the 176Lu-176Hf and 147Sm-143Nd systematics of shergottites. Earth and Planetary Science Letters 269, 186-199.

Debaille, V., Van Orman, J., Yin, Q.-Z., Amelin, Y., 2017. The role of phosphates for the Lu-Hf chronology of meteorites. Earth and Planetary Science Letters 473, 52-61.

Debruyne, D., Hulsbosch, N., Van Wilderode, J., Balcaen, L., Vanhaecke, F., Muchez, P., 2015. Regional geodynamic context for the Mesoproterozoic Kibara Belt (KIB) and the Karagwe-Ankole Belt: Evidence from geochemistry and isotopes in the KIB. Precambrian Research 264, 82-97. 
Decrée, S., Boulvais, P., Cobert, C., Baele, J.-M., Gardien, V., Tack, L., Demaiffe, D., 2015. Mineralogical, geochemical and isotopic ( $\mathrm{C}$ and $\mathrm{O})$ characterization of a complex (REE and HFSE) mineralized system related to the Matongo carbonatite (Burundi). Precambrian Research 269, 281-295.

Decrée, S., Boulvais, P., Tack, L., André, L., Baele, J.-M., 2016. Fluorapatite in carbonatite-related phosphate deposits: the case of the Matongo carbonatite (Burundi). Mineralium Deposita 51, 453-466.

Delpomdor, F., Linnemann, U., Boven, A., Gärtner, A., Travin, A., Blanpied, C., Virgone, A., Jelsma, H., Préat, A., 2013. Depositional age, provenance, tectonic and paleoclimatic settings of the late Mesoproterozoicmiddle Neoproterozoic Mbuji-Mayi Supergroup, Democratic Republic of Congo. Palaeogeography, Palaeoclimatology, Palaeoecology 389, 4-34.

Delvaux, D., Kervyn, F., Macheyeki, A. S., et al., 2012. Geodynamic significance of the TRM segment in the East African Rift (W-Tanzania): Active tectonics and paleostress in the Ufipa plateau and Rukwa basin. Journal of Structural Geology 37, 161-180.

Demaiffe, D., 2008. Le magmatisme alcalin et carbonatitique: Synthèse sur la province paléozoïque de Kola (Russie) et caractéristiques générales du massif protérozoïque de Matongo (Burundi). Bulletin des Séances de l'Académie Royale des Sciences d'Outre-Mer 54, 171-196.

Dewaele, S., Henjes-Kunst, F., Melcher, F., Sitnikova, M., Burgess, R., Gerdes, A., Fernandez-Alonso, M, De Clercq, F., Muchez, P., Lehmann, B., 2011. Late Neoproterozoic overprinting of the cassiterite and columbite-tantalite bearing pegmatites of the Gatumba area, Rwanda (Central Africa). Journal of African Earth Sciences 61, 10-26.

Doroshkevich, A.G., Veksler, I.V., Klemd, R., Khromova, E.A., Izbrodin, I.A., 2017. Trace-element composition of minerals and rocks in the Belaya Zima carbonatite complex (Russia): Implications for the mechanisms of magma evolution and carbonatite formation. Lithos 284-285, 91-108.

Downes, H., Balaganskaya, E., Beard, A., Liferovich, R., Demaiffe, D., 2005. Petrogenetic processes in the ultramafic, alkaline and carbonatitic magmatism in the Kola Alkaline Province: A review. Lithos 85, $48-75$.

Eby, G.N., 1985. Sr and Pb isotopes, $\mathrm{U}$ and Th chemistry of the alkaline Monteregian and White Mountain igneous provinces, eastern North America. Geochimica et Cosmochimica Acta 49, 1143-1153. 
Ernst, R.E., and K.L. Buchan, 2003. Recognizing mantle plumes in the geological record. Annual Review of Earth and Planetary Sciences 31, 469-523.

Fernandez-Alonso, M., Cutten, H., De Waele, B., Tack, L., Tahon, A., Baudet, D., Barritt, S.D., 2012. The Mesoproterozoic Karagwe-Ankole Belt (formerly the NE Kibara Belt): The result of prolonged extensional intracratonic basin development punctuated by two short-lived far-field compressional events. Precambrian Research 216, 63-86.

Fransolet, A.-M., Tack, L., 1992. Les zircons de Matongo (Burundi) et leur signification. Annales de la Société géologique de Belgique 115, 113-118.

Freestone, I.C., Hamilton, D.L., 1980. The role of liquid immiscibility in the genesis of carbonatites - An experimental study. Contributions to Mineralogy and Petrology 73, 105-117.

Gieré, R., Sorensen, S.S., 2004. Allanite and other REE-rich epidote-group minerals. Reviews in Mineralogy and Geochemistry $56(1), 431-493$

Guzmics, T., Zajacz, Z., Mitchell, R.H., Szabó, C., Wälle, M., 2015. The role of liquid-liquid immiscibility and crystal fractionation in the genesis of carbonatite magmas: insights from Kerimasi melt inclusions. Contributions to Mineralogy and Petrology 169, 1-18.

Halama, R., Vennemann, T., Siebel, W., Markl, G., 2005. The Grønnedal-Ika carbonatite--syenite complex, South Greenland: Carbonatite formation by liquid immiscibility. Journal of Petrology 46, 191-217.

Hamilton, D. L., MacKenzie, W. S., 1965. Phase-equilibrium studies in the system $\mathrm{NaAlSiO}_{4}($ nepheline)$\mathrm{KAlSiO}_{4}$ (kalsilite)- $\mathrm{SiO}_{2}-\mathrm{H}_{2} \mathrm{O}$. Mineralogical Magazine 34, 214-231

Hanson, R.E., 2003. Proterozoic geochronology and tectonic evolution of southern Africa. Geological Society of London, Special Publications 206, 427-463.

Harmer, R.E., Gittins, J., 1998. The case for primary, mantle-derived carbonatite magma. Journal of Petrology 39, 1895-1903.

Harmer, R.E., 1999. The petrogenetic association of carbonatite and alkaline magmatism: Constraints from the Spitskop Complex, South Africa, Journal of Petrology 40, 525-548.

Harris, C., Marsh, J.S., Milner, S.C., 1999. Petrology of the alkaline core of the Messum igneous complex, Namibia: Evidence for the progressively decreasing effect of crustal contamination. Journal of Petrology 40, 1377-1397. 
Kampunzu, A.B., Lubala, R.T., Makutu, M.N., Caron, J.-P.H., Rocci, G., Vellutini, P.-J., 1985. Les complexes alcalins dans la region interlacustre à l'est du Zaïre et au Burundi. Un exemple de massifs anorogéniques de relaxation. Journal of African Earth Sciences 3, 151-167

Kampunzu, A.B., Kramers, J., Tembo, F., 1997. Neoproterozoic alkaline and carbonatite magmatism along the western rift in Central-Eastern Africa: Break-up of Rodinia supercontinent and reconstruction of Gondwana. Gondwana Research 1, 155-156.

Kjarsgaard, B. A., 1998. Phase relations of a carbonated high-CaO nephelinite at 0.2 and 0.5 GPa. Journal of Petrology 39, 2061-2075.

Klerkx, J., Theunissen, K., Delvaux, D., 1998. Persistent fault controlled basin formation since the Proterozoic along the Western Branch of the East African Rift. Journal of African Earth Sciences 26, 347-361.

Landoll, J.D., Foland, K.A., Henderson, C.M.B., 1994. Nd isotopes demonstrate the role of contamination in the formation of coexisting quartz and nepheline syenites at the Abu Khruq Complex, Egypt. Contributions to Mineralogy and Petrology 117, 305-329.

Lee, W.-J., Wyllie, P.J., 1994. Experimental data bearing on liquid immiscibility, crystal fractionation, and the origin of calciocarbonatites and natrocarbonatites. International Geology Review 36, 797-819.

Le Maitre, R.W., Streckeisen, A., Zanettin, B., Le Bas, M.J., Bonin, B., Bateman, P., Bellieni, G., Dudek, A., Efremova, S., Keller, J., Lameyre, J., Sabine, P.A., Schmid, R., Sørensen, H., Woolley, A.R., 2002. Igneous Rocks: A classification and glossary of terms. Recommendations of the International Union of Geological Sciences. Subcommission on the Systematics of Igneous Rocks. Cambridge University Press, 236p.

Li, Z.X., Bogdanova, S.V., Collins, A.S., Davidson, A., De Waele, B., Ernst, R.E., Fitzsimons, I.C.W., Fuck, R.A., Gladkochub, D.P., Jacobs, J., Karlstrom, K.E., Lu, S., Natapov, L.M., Pease, V., Pisarevsky, S.A., Thrane, K., Vernikovsky, V., 2008. Assembly, configuration, and break-up history of Rodinia: A synthesis. Precambrian Research 160, 179-210.

Liu, C. Z., Zhang, C., Liu, Z. C., Sun, J., Chu, Z. Y., Qiu, Z. L., Wu, F. Y., 2017. Formation age and metasomatism of the sub-continental lithospheric mantle beneath southeast China: Sr-Nd-Hf-Os isotopes of Mingxi mantle xenoliths. Journal of Asian Earth Sciences 145, 591-604. 
Martin, L.H., Schmidt, M.W., Mattsson, H.B., Ulmer, P., Hametner, K., Günther, D., 2012. Element partitioning between immiscible carbonatite-kamafugite melts with application to the Italian ultrapotassic suite. Chemical Geology 320, 96-112.

McDonough, W.F., 1990. Constraints on the composition of the continental lithospheric mantle. Earth and Planetary Science Letters 101, 1-18.

McDonough, W.F., Sun, S.-S., 1995. Composition of the Earth. Chemical Geology 120, 223-253.

Melcher, F., Graupner, T., Gäbler, H.E., Sitnikova, M., Henjes-Kunst, F., Oberthür, T., Gerdes, A., Dewaele, S., 2015. Tantalum-(niobium-tin) mineralisation in African pegmatites and rare metal granites: Constraints from $\mathrm{Ta}-\mathrm{Nb}$ oxide mineralogy, geochemistry and U-Pb geochronology. Ore Geology Reviews 64, 667719.

Midende, G., 1984. La carbonatite de Matongo (Burundi). Etude minéralogique, pétrologique et géochimique. Unpublished $\mathrm{PhD}$ thesis, Université Libre de Bruxelles, Bruxelles, 288 p.

Midende, G., Boulvais, P., Tack, L., Melcher, F., Gerdes, A., Dewaele, S., Demaiffe, D., Decrée, S., 2014. Petrography, geochemistry and U-Pb zircon age of the Matongo carbonatite Massif (Burundi): Implication for the Neoproterozoic geodynamic evolution of Central Africa. Journal of African Earth Sciences 100, 656-674.

Minarik, W.G., 1998. Complications to carbonate melt mobility due to the presence of an immiscible silicate melt. Journal of Petrology 39, 1965-1973.

Miyazaki, T., Kagami, H., Mohan, V. R., Shuto, K., Morikiyo, T., 2003. Enriched subcontinental lithospheric mantle in the northern part of the South Indian Granulite Terrain: evidence from Yelagiri and Sevattur syenite plutons, Tamil Nadu, South India. Gondwana Research 6, 585-594.

Morbidelli, L., Gomes, C. B., Brotzu, P., D’Acquarica, S., Garbarino, C., Ruberti, E., Traversa, G., 2000. The Pariquera Açu K-alkaline complex and southern Brazil lithospheric mantle source characteristics. Journal of Asian Earth Sciences 18, 129-150.

Pivin, M., Debaille, V., Mattielli, N., Demaiffe, D., 2013. Nd-Hf Isotope Systematics of Megacrysts from the Mbuji-Mayi Kimberlites, DR Congo: Evidence for a Metasomatic Origin Related to Kimberlite Interaction with the Cratonic Lithospheric Mantle. Proceedings of 10th International Kimberlite Conference 1, 123-136. 
Platt, R.G., 1996. Nepheline syenite complexes-an overview. In: R.H. Mitchell (Ed.) Undersaturated alkaline rocks: Mineralogy, petrogenesis, and economic potential. Mineralogical Association of Canada, Short Course Series 24, 63-99.

Riishuus, M. S., Peate, D. W., Tegner, C., Wilson, J. R., Brooks, C. K., Harris, C., 2006. Temporal evolution of a long-lived syenitic centre: The Kangerlussuaq Alkaline Complex, East Greenland. Lithos 92, 276-299.

Roulleau, E., Stevenson, R., 2013. Geochemical and isotopic (Nd-Sr-Hf-Pb) evidence for a lithospheric mantle source in the formation of the alkaline Monteregian Province (Quebec). Canadian Journal of Earth Sciences 50, 650-666.

Saha, A., Ganguly, S., Ray, J., Koeberl, C., Thöni, M., Sarbajna, C., Sawant, S. S., 2017. Petrogenetic evolution of Cretaceous Samchampi-Samteran Alkaline Complex, Mikir Hills, Northeastern India: Implications on multiple melting events of heterogeneous plume and metasomatized sub-continental lithospheric mantle. Gondwana Research 48, 237-256.

Schmidberger, S. S., Simonetti, A., Francis, D., Gariépy, C., 2002. Probing Archean lithosphere using the Lu-Hf isotope systematics of peridotite xenoliths from Somerset Island kimberlites, Canada. Earth and Planetary Science Letters 197, 245-259.

Simon, N. S., Carlson, R. W., Pearson, D. G., Davies, G. R., 2007. The origin and evolution of the Kaapvaal cratonic lithospheric mantle. Journal of Petrology 48, 589-625.

Sun, S.-S., 1982. Chemical composition and origin of the earth's primitive mantle. Geochimica et Cosmochimica Acta 46, 179-192.

Tack, L., De Paepe, P., Deutsch, S., Liégeois, J.-P., 1984. The alkaline plutonic complex of the Upper Ruvubu (Burundi): geology, age, isotopic geochemistry and implications for the regional geology of the Western

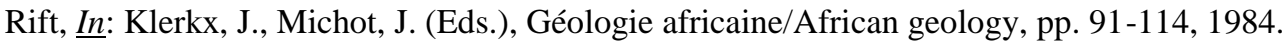

Tack, L., Liégeois, J. P., Deblond, A., Duchesne, J. C., 1994. Kibaran A-type granitoids and mafic rocks generated by two mantle sources in a late orogenic setting (Burundi). Precambrian research 68, 323356.

Tack, L., Liégeois, J.-P., André, L., Navez, J., 1995. The Upper Ruvubu alkaline plutonic complex (Burundi). Annual Report of the Royal Museum for Central Africa, Tervuren, p. 9. 
Tack, L., Deblond, A., De Paepe, P., Duchesne, J.C., Liégeois, J.-P., 1996. Proterozoic alignments of alkaline plutons revealing lithospheric discontinuities : Evidence from Eastern Africa, $\underline{I n}$ : Demaiffe, D. (Ed.), Petrology and Geochemistry of magmatic suites of rocks in the continental and oceanic crusts. A volume dedicated to Professor Jean Michot, Université Libre de Bruxelles, Bruxelles, Belgium, pp. 219226.

Tack, L., Wingate, M.T.D., De Waele, B., Meert, J., Belousova, E., Griffin, B., Tahon, A., Fernandez-Alonso, M., 2010. The 1375 Ma "Kibaran event" in Central Africa: Prominent emplacement of bimodal magmatism under extensional regime. Precambrian Research 180, 63-84.

Tappe, S., Foley, S.F., Stracke, A., Romer, R.L., Kjarsgaard, B.A., Heaman, L.M., Joyce, N., 2007. Craton reactivation on the Labrador Sea margins: ${ }^{40} \mathrm{Ar} /{ }^{39} \mathrm{Ar}$ age and $\mathrm{Sr}-\mathrm{Nd}-\mathrm{Hf}-\mathrm{Pb}$ isotope constraints from alkaline and carbonatite intrusives. Earth and Planetary Science Letters 256, 433-454.

Van den haute, P., 1986. Sphene fission-track dating of a precambrian alkaline pluton in Burundi (Central Africa). Terra Cognita 6, p. 65.

Veksler, I.V., Dorfman, A.M., Dulski, P., Kamenetsky, V.S., Danyushevsky, L.V., Jeffries, T., Dingwell, D.B., 2012. Partitioning of elements between silicate melt and immiscible fluoride, chloride, carbonate, phosphate and sulfate melts, with implications to the origin of natrocarbonatite. Geochimica et Cosmochimica Acta 79, 20-40.

Vergauwen, I., 1990. Mineralogisch en geochemisch onderzoek van de nefeliensyenieten van het alkalisch plutonisch complex van de Boven-Ruvubu (Burundi). MSc thesis, University of Gent, Belgium, 80 p.

Verhulst, A., Balaganskaya, E., Kirnarsky, Y., Demaiffe, D., 2000. Petrological and geochemical (trace elements and $\mathrm{Sr}-\mathrm{Nd}$ isotopes) characteristics of the Paleozoic Kovdor ultramafic, alkaline and carbonatite intrusion (Kola Peninsula, NW Russia). Lithos 51, 1-25.

Weis, D., Kieffer, B., Maerschalk, C., Barling, J., de Jong, J., Williams, G.A., Hanano, D., Pretorius, W., Mattielli, N., Scoates, J.S., Goolaerts, A., Friedman, R.M., Mahoney, J.B., 2006. High-precision isotopic characterization of USGS reference materials by TIMS and MC-ICP-MS, GCubed 7, doi:10.1029/2006GC001283

Woolley, A.R., 2001. Alkaline rocks and carbonatites of the world. Part 3: Africa, Geological Society of London, 372 p. 
Woolley, A.R., Kjarsgaard, B.A., 2008. Paragenetic types of carbonatite as indicated by the diversity and relative abundances of associated silicate rocks: Evidence from a global database. The Canadian Mineralogist $46,741-752$.

Xu, H., Zhang, J., Wang, Y., Liu, W., 2016. Late Triassic alkaline complex in the Sulu UHP terrane: Implications for post-collisional magmatism and subsequent fractional crystallization. Gondwana Research 35, 390-410.

Zhu, Y.S., Yang, J.-H., Sun, J.F., Zhang, J.-H., Wu, F.-Y., 2016. Petrogenesis of coeval silica-saturated and silica-undersaturated alkaline rocks: Mineralogical and geochemical evidence from the Saima alkaline complex, NE China. Journal of Asian Earth Sciences 117, 184-207

\section{Figure and table captions}

Figure 1. (A) Geological sketch map of the study area (after Tack et al., 1984, modified and redrawn, and Fernandez-Alonso et al., 2012). The insert shows the location of alkaline complexes occurring along the Western Rift, including the URAPC (after Tack et al., 1984, redrawn). (B) Location of all rock samples from the URAPC reported in this work.

Figure 2. Selected field pictures and macrophotographs of URAPC rocks. (A) An undeformed block of granite in the Buraniro area. (B) A cataclastic granite from the Buraniro area. (C) A gabbroic xenolith in the Buraniro granite. (D) A strongly deformed quartz-bearing syenite (mylonitic facies). (E) A feldspathoidal syenite presenting magmatic layering. (F) A deformed and foliated syenite. (G) Blue sodalite and yellow to pinkish cancrinite in a rock sample collected west of Kiziba (see Fig. 1B). 
Figure 3. Photomicrographs of URAPC rocks using plane-polarized (A, G and H-insert) and crossed-polarized (B, C, D, E, F and H) light. Abbreviations are the following: Amp: amphibole, Bt: biotite, Ccn: cancrinite, Cpx: clinopyroxene, Grt: garnet, Kfs: K-feldspar, Nph: nepheline, Ol: olivine, Pl: plagioclase, Pcl: pyrochlore, Qz: quartz, Sdl: sodalite, and Ttn: titanite. (A and B): Hypidiomorphic-granular texture in a gabbro (LT26); the Bowen discontinuous reaction series is illustrated by rims of amphibole and biotite around olivine; $\mathrm{C}$ : A mafic cluster in a quartz-bearing syenite (LT566); D: Cataclastic texture in a granite (LT956); E: Hypidiomorphic-granular texture and typical mineral assemblage of a feldspathoidal syenite (LT36); F: Replacement of nepheline by cancrinite in a foid-bearing syenite (LT259); G: Interstitial garnet in a feldspathoidal syenite (LT36); H: Feldspathoidal syenite with layering evidenced by grain size variation and orientation of the constituent minerals. Notice a large perthitic alkali felspar to the left, and a fine-grained mix of alkali feldspar and nepheline to the right. The insert shows euhedral crystals of titanite and pyrochlore, two accessory minerals frequently appearing in the layered syenites (LT1076).

Figure 4. (A) The analysed rocks in the $\mathrm{Na}_{2} 0+\mathrm{K}_{2} \mathrm{O}$ vs. silica classification diagram introduced by Le Maitre et al., 2002; (B-I, K) Binary plots showing major, minor and $\Sigma$ REE contents vs. $\mathrm{SiO}_{2}$, and (J, L and M) plots of $\mathrm{Eu} / \mathrm{Eu}^{*}$ ratios vs. $\mathrm{SiO}_{2}, \mathrm{La}_{\mathrm{N}} / \mathrm{Yb}_{\mathrm{N}}$ ratios vs. $\Sigma \mathrm{REE}$, and EREE vs. $\mathrm{P}_{2} \mathrm{O}_{5}$, respectively. Data from this work, and from Vergauwen (1990) and Buysschaert (1993).

Figure 5. REE patterns (A-D) and spidergrams (E-H) of URAPC rocks (data from this study, and from Vergauwen, 1990 and Buysschaert, 1993). A and E: rocks of the gabbro-diorite group; B and F: quartz-bearing syenites; C and G: granites; D and H: feldspathoidal syenites. The domain where the Matongo carbonatite (see $\mathrm{H}$ ) plots is given for comparison purposes 
(Midende et al., 2014). Normalization to the chondrites (Sun, 1982, and McDonough, 1990) for the REE, and to the Primitive Mantle (McDonough and Sun, 1995).

Figure 6. (A) Initial $\varepsilon N d$ vs. ${ }^{87} \mathrm{Sr}^{86} \mathrm{Sr}_{(\mathrm{i})}$ and (B) Initial $\varepsilon H f$ vs. $\varepsilon N \mathrm{Nd}_{(\mathrm{i})}$ isotopic diagrams for the URAPC samples. Data related to the Matongo carbonatite are from Demaiffe (2008).

Figure 7. Correlation between (A) ${ }^{87} \mathrm{Sr}^{86}{ }^{8 \mathrm{Sr}_{(\mathrm{i})}}$ and $\mathrm{SiO}_{2}$ content, and (B) between ${ }^{87} \mathrm{Sr} /{ }^{86} \mathrm{Sr}_{(\mathrm{i})}$ and 1/Sr. Data from this study and from Tack et al. (1984) for the Sr isotopic data, and from this study, Vergauwen (1990) and Buysschaert (1993) for the $\mathrm{SiO}_{2}$ contents (cf. Tables 2, 3 and 4).

Figure 8. (A) Initial ${ }^{143} \mathrm{Nd} /{ }^{144} \mathrm{Nd}_{(\mathrm{i})}$ vs. ${ }^{87} \mathrm{Sr} /{ }^{86} \mathrm{Sr}_{(\mathrm{i})}$ diagram for the URAPC samples. Data with regard to the Matongo carbonatite are from Demaiffe (2008). The country-rocks field is defined after data from Tack et al. (1994) and Debruyne et al. (2015). (B) Initial $\varepsilon H f$ vs. $\varepsilon N d$ for the URAPC samples. Fields reported for comparison: Depleted Mantle (DM), Modern OIB, HIMU Reservoir, and a Neoproterozoic (582 Ma) carbonatite suite associated with ultramafic lamprophyres (UML) exposed along the Labrador Sea (Tappe et al., 2007); SCLM xenolith from Mingxi peridotite (Liu et al., 2017), Somerset Island kimberlites (Schmidberger et al., 2002), and Kaapvaal Craton peridotites (Simon et al., 2007).

Table 1. Succinct description of all examined URAPC samples.

Table 2. Major element composition (in wt. \%) of the studied URAPC rocks. Analyses carried out at the ULB "G-Time" Laboratories. Reference numbering is as follows: (*) This study, the others are from Buysschaert (1993) and Vergauwen (1990). 
Table 3. Trace element content (in ppm), $\mathrm{La}_{\mathrm{N}} / \mathrm{Yb}_{\mathrm{N}}$ ratio, $\mathrm{Ce} * / \mathrm{Ce}$ ratio, Eu*/Eu ratio and $\Sigma \mathrm{REE}$ contents of the examined URAPC rocks. Analyses carried out at the ULB "G-Time" Laboratories. Reference numbering is as follows: (*) This study and from Buysschaert (1993) and Vergauwen (1990).

Table 4. Measured and initial $\mathrm{Sr}$, Nd and Hf isotopic composition of the studied URAPC rocks. Initial ratios are recalculated at $705 \mathrm{Ma}$ (Midende et al., 2014). Analyses were carried out at the ULB "G-Time" Laboratories. Reference numbering is as follows: (*) This study, the others are from Tack et al. (1984). 


\begin{tabular}{|c|c|c|c|}
\hline $\begin{array}{l}\text { Sample } \\
\text { no. }\end{array}$ & $\begin{array}{l}\text { RMCA } \\
\text { code }\end{array}$ & $\begin{array}{l}\text { Coordinates (Long.; } \\
\text { Lat.) }\end{array}$ & Rock type \\
\hline \multicolumn{4}{|l|}{$\begin{array}{l}\text { Outer } \\
\text { Unit }\end{array}$} \\
\hline LT 1 & RG134240 & $\begin{array}{l}29^{\circ} 33^{\prime} 52.0^{\prime \prime E} \\
2^{\circ} 58^{\prime} 46.3^{\prime \prime S}\end{array}$ & Monzodiorite \\
\hline LT 26 & RG134262 & $\begin{array}{l}29^{\circ} 34^{\prime} 12.7 " \mathrm{E} \\
2^{\circ} 57^{\prime} 06.8^{\prime \prime S}\end{array}$ & Gabbro \\
\hline LT 95 & RG134324 & $\begin{array}{l}29^{\circ} 33^{\prime} 29.6 " \mathrm{E} \\
3^{\circ} 00^{\prime} 21.4 " \mathrm{~S}\end{array}$ & Gabbro in contact with quartz-bearing syenite \\
\hline LT 210 & RG134425 & $\begin{array}{l}29^{\circ} 38^{\prime} 03.1 " \mathrm{E} \\
2^{\circ} 58^{\prime} 58.8^{\prime \prime S}\end{array}$ & Gabbro \\
\hline LT 317 & RG134525 & $\begin{array}{l}29^{\circ} 32^{\prime} 55.3^{\prime \prime E} \\
2^{\circ} 58^{\prime} 06.2^{\prime \prime S}\end{array}$ & Gabbro \\
\hline LT 340 & RG134546 & $\begin{array}{l}29^{\circ} 34^{\prime} 09.1 " \mathrm{E} \\
2^{\circ} 57^{\prime} 09.5^{\prime \prime S}\end{array}$ & Quartz-bearing monzogabbro \\
\hline LT 342 & RG134548 & $\begin{array}{l}29^{\circ} 32 ' 26.0^{\prime \prime} \mathrm{E} \\
2^{\circ} 57^{\prime} 15.0^{\prime \prime S}\end{array}$ & Diorite \\
\hline LT 347 & RG134552 & $\begin{array}{l}29^{\circ} 32^{\prime} 22.0^{\prime \prime E} \\
2^{\circ} 57^{\prime} 14.6 " \mathrm{~S}\end{array}$ & Diorite \\
\hline LT 350 & RG134554 & $\begin{array}{l}29^{\circ} 32^{\prime} 17.3^{\prime \prime} \mathrm{E} \\
2^{\circ} 57^{\prime} 36.0^{\prime \prime S}\end{array}$ & Diorite \\
\hline LT1006 & RG144616 & $\begin{array}{l}29^{\circ} 39^{\prime} 14.8 " \mathrm{E} \\
3^{\circ} 05^{\prime} 49.8 " \mathrm{~S}\end{array}$ & Gabbro \\
\hline LT 1017 & RG144626 & $\begin{array}{l}29^{\circ} 40^{\prime} 10.7 " \mathrm{E} \\
3^{\circ} 05^{\prime} 33.9^{\prime \prime S}\end{array}$ & Quartz monzodiorite \\
\hline LT 1061 & RG144670 & $\begin{array}{c}29^{\circ} 37^{\prime} 47.9^{\prime \prime} \mathrm{E} \\
3^{\circ} 05^{\prime} 36.2 " \mathrm{~S}\end{array}$ & Quartz monzodiorite \\
\hline GPS 9+ & & $29^{\circ} 38^{\prime} 48.5^{\prime \prime} \mathrm{E} ; 3^{\circ} 02^{\prime} 2.3^{\prime \prime S}$ & Gabbro \\
\hline GPS 11 & & $\begin{array}{l}29^{\circ} 38^{\prime} 57.5 " \mathrm{E} \\
3^{\circ} 02^{\prime} 18.0^{\prime \prime S}\end{array}$ & Gabbro \\
\hline GPS 38 & & $\begin{array}{l}29^{\circ} 32^{\prime} 37.3^{\prime \prime E} \\
2^{\circ} 57^{\prime} 09.4^{\prime \prime S}\end{array}$ & Gabbro \\
\hline GPS 80 & & $29^{\circ} 37^{\prime} 55.1 " \mathrm{E} ; 3^{\circ} 0^{\prime} 34.1 " \mathrm{~S}$ & Gabbro \\
\hline LT 60 & $R G 134291$ & $\begin{array}{l}29^{\circ} 33^{\prime} 34.5 " \mathrm{E} \\
2^{\circ} 58^{\prime} 52.6^{\prime \prime} \mathrm{S}\end{array}$ & Quartz-bearing syenite \\
\hline LT 288 & $R G 134496$ & $\begin{array}{l}29^{\circ} 33^{\prime} 45.3^{\prime \prime} \mathrm{E} \\
2^{\circ} 57^{\prime} 16.4^{\prime \prime S}\end{array}$ & Quartz-bearing syenite \\
\hline LT 318 & RG134526 & $\begin{array}{l}29^{\circ} 32^{\prime} 59.0^{\prime \prime E} \\
2^{\circ} 57^{\prime} 57.4 " S\end{array}$ & Quartz-bearing syenite \\
\hline LT 693 & RG134685 & $\begin{array}{l}29^{\circ} 33^{\prime} 38.2 " E ; \\
2^{\circ} 59^{\prime} 53.3 " S\end{array}$ & Quartz-bearing syenite \\
\hline LT 993 & RG144605 & $\begin{array}{l}29^{\circ} 34^{\prime} 22.0^{\prime \prime E} \\
3^{\circ} 01^{\prime} 21.0 " \mathrm{~S}\end{array}$ & Quartz-bearing syenite \\
\hline LT 1133 & RG144738 & $\begin{array}{l}29^{\circ} 32^{\prime} 58.6^{\prime \prime} \mathrm{E} \\
2^{\circ} 58^{\prime} 06.4^{\prime \prime S}\end{array}$ & Quartz-bearing syenite \\
\hline LT 485 & RG134681 & $\begin{array}{l}29^{\circ} 39^{\prime} 47.6^{\prime \prime} \mathrm{E} \\
3^{\circ} 06^{\prime} 37.3^{\prime \prime S}\end{array}$ & Quartz-bearing syenite \\
\hline LT 486 & RG134682 & $\begin{array}{l}29^{\circ} 39^{\prime} 03.1 " \mathrm{E} \\
3^{\circ} 02^{\prime 2} 29.2^{\prime \prime S}\end{array}$ & Quartz-bearing syenite \\
\hline LT 566 & RG134760 & $\begin{array}{l}29^{\circ} 38^{\prime} 45.6 " \mathrm{E} \\
3^{\circ} 01^{\prime} 35.8^{\prime \prime S}\end{array}$ & Quartz-bearing syenite \\
\hline LT 1041 & RG144650 & $\begin{array}{l}29^{\circ} 39^{\prime} 04.9^{\prime \prime} \mathrm{E} \\
3^{\circ} 02^{\prime} 28.4^{\prime \prime S}\end{array}$ & Quartz-bearing syenite \\
\hline GPS 6 & & $\begin{array}{l}29^{\circ} 38^{\prime} 47.3^{\prime \prime E} \\
3^{\circ} 01^{\prime} 24.1^{\prime \prime S}\end{array}$ & Quartz-bearing syenite \\
\hline GPS 9 & & $\begin{array}{l}29^{\circ} 38^{\prime} 47.0^{\prime \prime} \mathrm{E} \\
3^{\circ} 01^{\prime} 37.2^{\prime \prime S}\end{array}$ & Quartz-bearing syenite \\
\hline GPS 36 & & 29³2'34.4"E; & Strongly albitized quartz-bearing syenite \\
\hline
\end{tabular}




\begin{tabular}{|c|c|c|c|}
\hline LT 96 & RG134325 & $\begin{array}{c}29^{\circ} 33^{\prime 2} 29.2 " \mathrm{E} ; \\
3^{\circ} 00^{\prime} 22.3^{\prime \prime S}\end{array}$ & Granite \\
\hline LT 321 & RG134528 & $\begin{array}{c}29^{\circ} 32^{\prime} 17.5^{\prime \prime E} \\
2^{\circ} 57^{\prime} 55.2^{\prime \prime S}\end{array}$ & Granite \\
\hline LT 956 & $R G 144569$ & $\begin{array}{c}29^{\circ} 33^{\prime 2} 29.9^{\prime \prime E} \\
3^{\circ} 00^{\prime} 22.0^{\prime \prime S}\end{array}$ & Granite \\
\hline LT 1011 & RG144621 & $\begin{array}{c}29^{\circ} 39^{\prime} 47.6^{\prime \prime E} \\
3^{\circ} 06^{\prime} 37.3^{\prime \prime S}\end{array}$ & Granite \\
\hline LT 1111 & $\mathrm{RG} 144716$ & $\begin{array}{c}29^{\circ} 37^{\prime} 54.3^{\prime \prime E} \\
3^{\circ} 02^{\prime} 38.2^{\prime \prime S}\end{array}$ & Granite \\
\hline LT 1112 & RG144717 & $\begin{array}{c}29^{\circ} 37^{\prime} 54.7^{\prime \prime E} \\
3^{\circ} 02^{\prime} 38.4^{\prime \prime S}\end{array}$ & Granite \\
\hline LT 929 & RG144542 & $\begin{array}{c}29^{\circ} 33^{\prime} 38.2^{\prime \prime E} \\
2^{\circ} 59^{\prime} 53.3^{\prime \prime S}\end{array}$ & Granite \\
\hline LT 977 & RG144590 & $\begin{array}{c}29^{\circ} 34^{\prime} 03.3^{\prime \prime E} \\
3^{\circ} 01^{\prime} 05.2^{\prime \prime S}\end{array}$ & Granite \\
\hline LT 1034 & RG144643 & $\begin{array}{c}29^{\circ} 39^{\prime} 38.9^{\prime \prime E} \\
3^{\circ} 03^{\prime} 15.4 " \mathrm{~S}\end{array}$ & Granite \\
\hline
\end{tabular}

\begin{tabular}{|c|c|c|c|}
\hline $\begin{array}{l}\text { Inner } \\
\text { Unit }\end{array}$ & & & \\
\hline LT 36 & RG134268 & $\begin{array}{l}29^{\circ} 36^{\prime} 07.4 " \mathrm{E} \\
2^{\circ} 58^{\prime} 50.8^{\prime \prime S}\end{array}$ & $\begin{array}{l}\text { Feldspathoidal syenite - hypidiomorphic- } \\
\text { granular }\end{array}$ \\
\hline LT 46 & RG134278 & $\begin{array}{l}29^{\circ} 36^{\prime} 53.9^{\prime \prime} \mathrm{E} \\
2^{\circ} 58^{\prime} 21.5^{\prime \prime S}\end{array}$ & Feldspathoidal syenite - trachytic \\
\hline LT 105 & RG134333 & $\begin{array}{l}29^{\circ} 37^{\prime} 51.7 " \mathrm{E} \\
2^{\circ} 56^{\prime} 54.4^{\prime \prime S}\end{array}$ & $\begin{array}{l}\text { Feldspathoidal syenite - hypidiomorphic- } \\
\text { granular }\end{array}$ \\
\hline LT111 & RG134338 & $\begin{array}{l}29^{\circ} 37^{\prime} 25.8 " \mathrm{E} \\
2^{\circ} 58^{\prime} 10.6 " \mathrm{~S}\end{array}$ & $\begin{array}{l}\text { Feldspathoidal syenite - hypidiomorphic- } \\
\text { granular }\end{array}$ \\
\hline LT134 & RG134360 & $\begin{array}{l}\text { 3"E; } \\
\text { 6"S }\end{array}$ & $\begin{array}{l}\text { Feldspathoidal syenite - hypidiomorphic- } \\
\text { granular }\end{array}$ \\
\hline LT629 & & $\begin{array}{l}\text { 35.6"E; } \\
\text { 3.1"S }\end{array}$ & $\begin{array}{l}\text { Feldspathoidal syenite - hypidiomorphic- } \\
\text { granular }\end{array}$ \\
\hline LT253 & RG134465 & $\begin{array}{l}29^{\circ} 36^{\prime} 46.9^{\prime \prime} \mathrm{E} \\
3^{\circ} 01^{\prime} 24.4^{\prime \prime S}\end{array}$ & $\begin{array}{l}\text { Feldspathoidal syenite - hypidiomorphic- } \\
\text { granular }\end{array}$ \\
\hline LT 259 & RG13 & $\begin{array}{l}29^{\circ} 36^{\prime} 35.6 " \mathrm{E} \\
3^{\circ} 01^{\prime} 55.8 " \mathrm{~S}\end{array}$ & $\begin{array}{l}\text { Feldspathoidal syenite - hypidiomorphic- } \\
\text { granular }\end{array}$ \\
\hline & & $\begin{array}{l}29^{\circ} 36^{\prime} 53.2 " \mathrm{E} \\
3^{\circ} 02^{\prime 2} 27.8 " \mathrm{~S}\end{array}$ & $\begin{array}{l}\text { Feldspathoidal syenite - hypidiomorphic- } \\
\text { granular }\end{array}$ \\
\hline LT512 & RG134708 & $\begin{array}{l}29^{\circ} 35^{\prime} 00.9 " E \\
2^{\circ} 57^{\prime} 32.0^{\prime \prime S}\end{array}$ & Feldspathoidal syenite - porphyritic \\
\hline LT590 & RG134782 & $\begin{array}{l}29^{\circ} 36^{\prime} 02.3^{\prime \prime} \mathrm{E} \\
3^{\circ} 01^{\prime} 48.5 " \mathrm{~S}\end{array}$ & $\begin{array}{l}\text { Feldspathoidal syenite - hypidiomorphic- } \\
\text { granular }\end{array}$ \\
\hline LT595 & RG134787 & $\begin{array}{l}29^{\circ} 36^{\prime} 00.9^{\prime \prime E} \\
3^{\circ} 01^{\prime} 35.5 " S\end{array}$ & Feldspathoidal syenite - porphyritic \\
\hline LT596 & RG134788 & $\begin{array}{l}29^{\circ} 36^{\prime} 01.0 " \mathrm{E} \\
3^{\circ} 01 ' 34.9^{\prime \prime S}\end{array}$ & Feldspathoidal syenite - porphyritic \\
\hline LT623 & RG134814 & $\begin{array}{l}29^{\circ} 35^{\prime} 12.7 " \mathrm{E} \\
3^{\circ} 01 \text { '30.8"S }\end{array}$ & Feldspathoidal syenite - porphyritic \\
\hline LT1076 & RG144684 & $\begin{array}{l}29^{\circ} 36 ' 38.0 " \mathrm{E} \\
3^{\circ} 00^{\prime} 09.2^{\prime \prime S}\end{array}$ & Feldspathoidal syenite - layered \\
\hline GPS 49 & & $\begin{array}{l}29^{\circ} 33^{\prime} 19.9^{\prime \prime E} \\
2^{\circ} 57^{\prime} 14.1 " \mathrm{~S}\end{array}$ & Feldspathoidal syenite \\
\hline
\end{tabular}




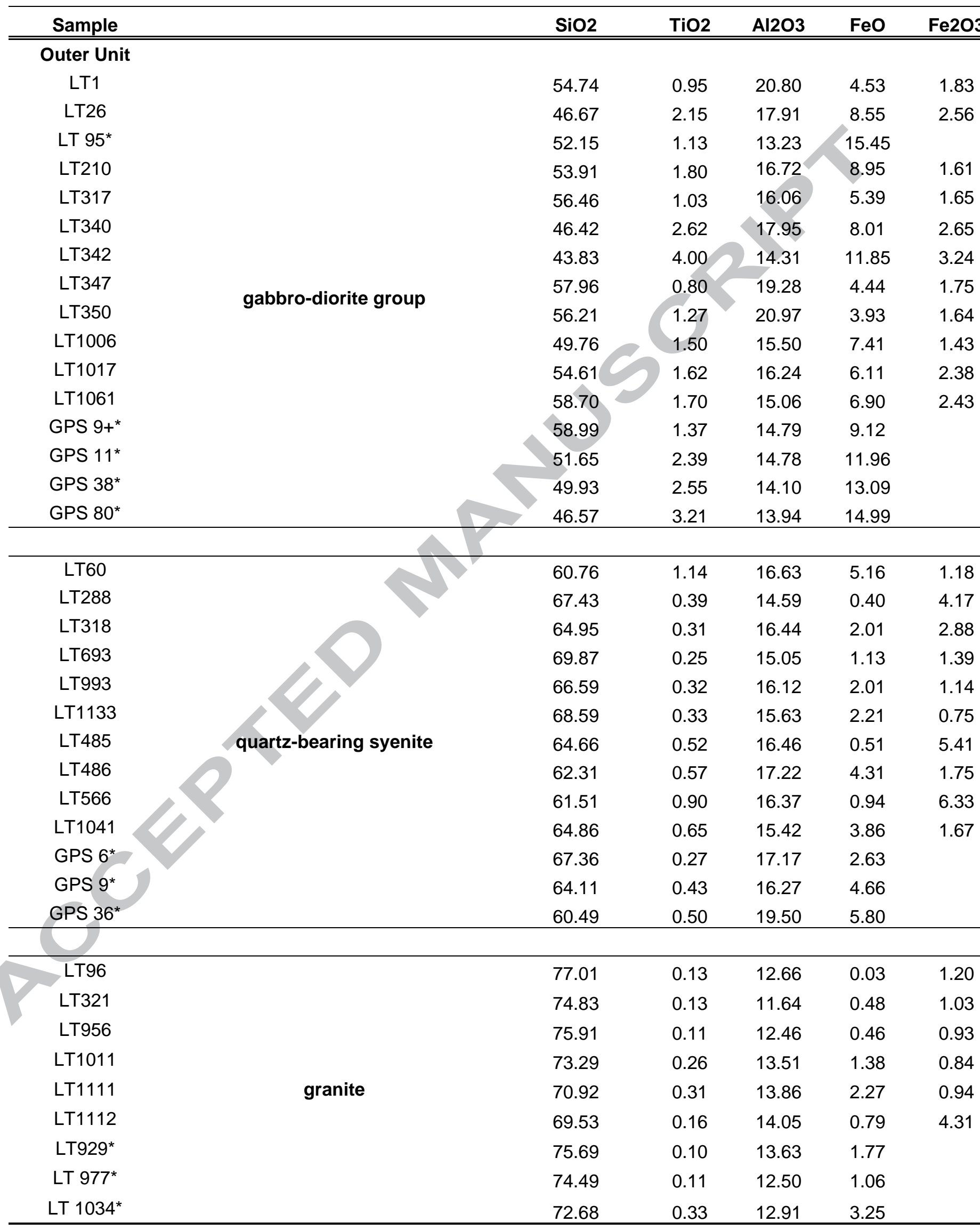

Inner Unit 


\begin{tabular}{|c|c|c|c|c|c|c|}
\hline LT36 & & 56.74 & 0.17 & 20.88 & 2.64 & 1.94 \\
\hline LT46* $^{*}$ & \multirow{13}{*}{ feldspathoidal syenite } & 58.25 & 0.08 & 20.84 & 4.16 & \\
\hline LT105 & & 57.53 & 0.06 & 20.13 & 1.08 & 3.75 \\
\hline LT111 & & 45.96 & 2.88 & 14.40 & 9.85 & 3.74 \\
\hline LT134 & & 46.42 & 1.72 & 14.74 & 7.33 & 2.85 \\
\hline LT629 & & 50.26 & 1.11 & 20.72 & 4.75 & 2.58 \\
\hline LT253 & & 47.49 & 1.27 & 20.97 & 4.77 & 2.99 \\
\hline LT479* & & 54.68 & 0.40 & 13.60 & 12.13 & \\
\hline LT512* & & 62.11 & 0.34 & 18.66 & 4.57 & \\
\hline LT590* & & 61.17 & 0.25 & 18.14 & 4.87 & \\
\hline LT595 & & 57.14 & 0.06 & 21.95 & 0.66 & 0.73 \\
\hline LT596* & & 58.16 & 0.15 & 20.32 & 2.68 & \\
\hline LT623 & & 56.87 & 0.24 & 21.70 & 1.49 & 1.12 \\
\hline GPS $49^{*}$ & & 59.31 & 0.33 & 19.36 & 5.76 & \\
\hline BHVO-2 & & 50.44 & 2.74 & 13.55 & & 12.80 \\
\hline AGV-2 & & 59.33 & 0.97 & 16.89 & & 6.55 \\
\hline
\end{tabular}

${ }^{*}$ Analysed at the Laboratoire G-Time-ULB. Reproductibility is better than $2 \%$.

Other analyses are from Vergauwen (1990) for the Inner Unit, and from Buysschaert (1993) for the Outer Unit

\begin{tabular}{|c|c|c|c|c|c|c|c|}
\hline Sample & 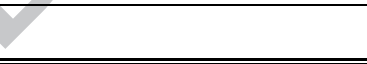 & $\mathbf{V}$ & $\mathbf{R b}$ & $\mathrm{Sr}$ & $\mathbf{Y}$ & $\mathrm{Zr}$ & $\mathbf{N}$ \\
\hline \multicolumn{8}{|l|}{ Outer Unit } \\
\hline LT1 & \multirow{14}{*}{ gabbro-diorite group } & 34 & 74 & 878 & 23 & 188 & 61 \\
\hline LT26 & & 121 & 22 & 950 & 24 & 120 & 5 \\
\hline LT $95^{\star}$ & & & 5.5 & 103 & 25 & 22.3 & 4. \\
\hline LT340 & & 156 & 34 & 903 & 28 & 124 & $4 i$ \\
\hline LT342 & & 132 & 60 & 525 & 40 & 176 & 7 \\
\hline LT347 & & 21 & 87 & 611 & 30 & 330 & 10 \\
\hline LT350 & & 49 & 79 & 931 & 23 & 130 & \\
\hline LT1006 & & 172 & 41 & & 19 & 133 & \\
\hline LT1017 & & 160 & 102 & & 31 & 209 & $v_{6}$ \\
\hline LT1061 & & 116 & 134 & & 47 & 283 & 8 \\
\hline GPS $9+^{*}$ & & & 134 & 311 & 42 & 310 & 68 \\
\hline GPS $11^{*}$ & & & 92 & 393 & 37 & 113 & 9 \\
\hline GPS 38 & & & 70 & 416 & 45 & 46 & 48 \\
\hline GPS $80^{*}$ & & & 66 & 348 & 39 & 113 & $6 !$ \\
\hline LT60 & \multirow{8}{*}{$\begin{array}{l}\text { quartz-bearing } \\
\text { syenite }\end{array}$} & 75 & 163 & 416 & 41 & 271 & $7 !$ \\
\hline LT288 & & 0.79 & 167 & 29 & 438 & 699 & 13 \\
\hline LT318 & & 11 & 183 & 142 & 46 & 437 & \\
\hline LT693 & & 10 & 139 & 102 & 62 & 489 & 10 \\
\hline LT993 & & 1.2 & 170 & & 121 & 748 & 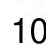 \\
\hline LT1133 & & 5.5 & 189 & 72 & 58 & 483 & \\
\hline LT485 & & 2.4 & 116 & 56 & 45 & 996 & \\
\hline LT486 & & 8.6 & 128 & 132 & 64 & 1104 & \\
\hline
\end{tabular}




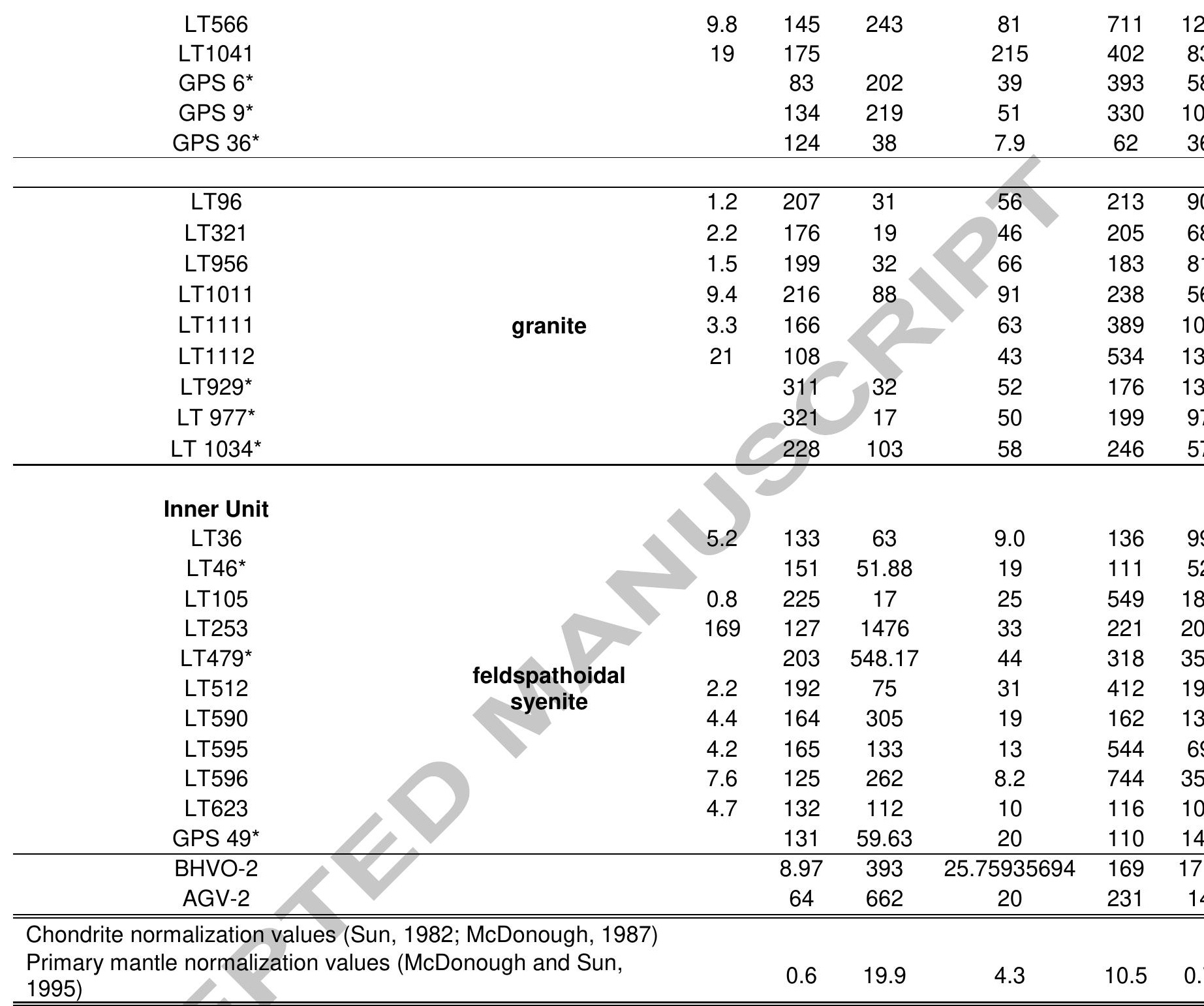

* Analysed at the Laboratoire G-Time-ULB

Other analyses are from Vergauwen (1990) for the Inner Unit, and from Buysschaert (1993) for the Outer Unit 


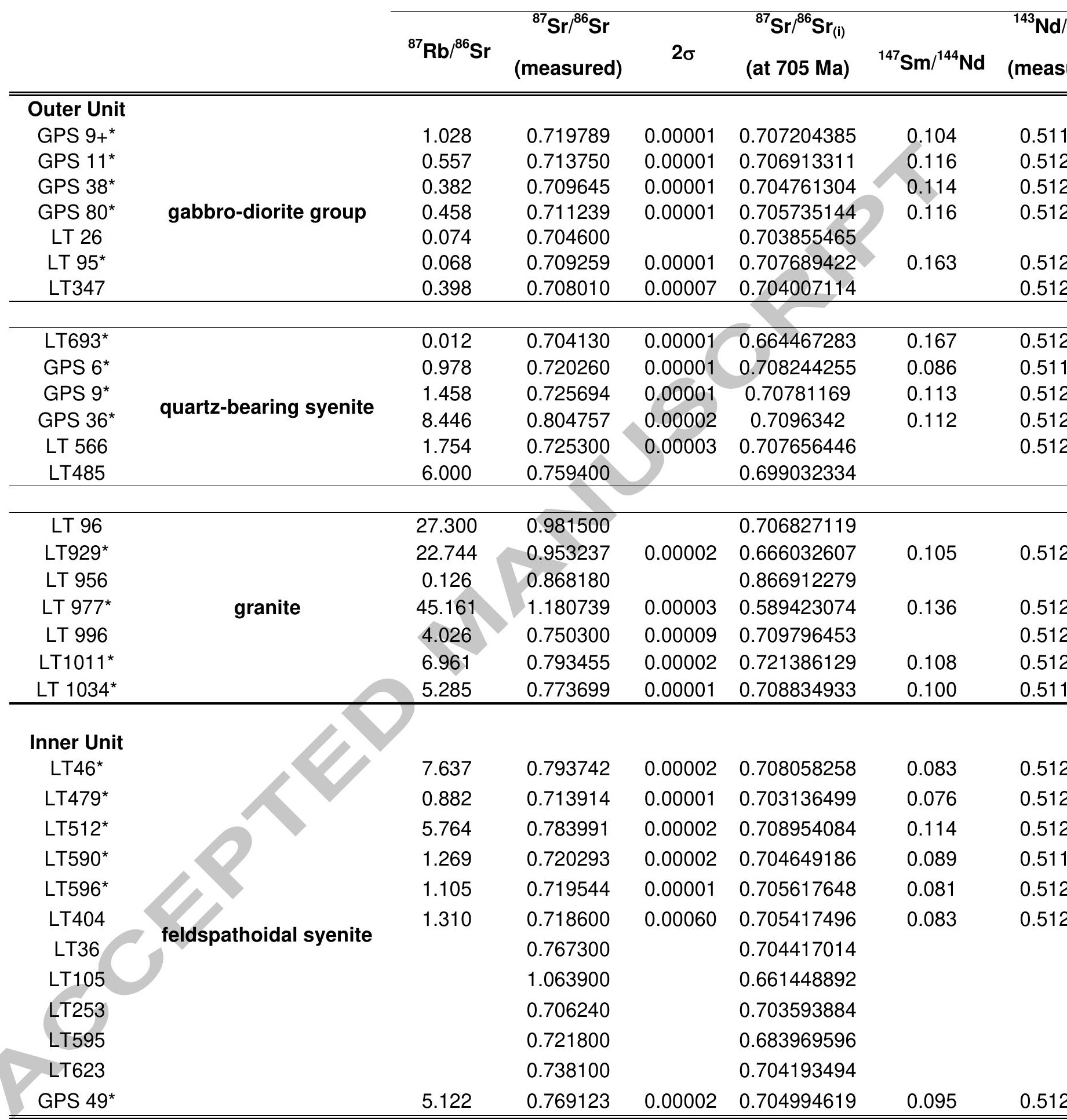

* Analysed at the Laboratoire G-TimeULB

Other analyses are from Tack et al. (1984)

Ratios and decay constants used: $\left({ }^{147} \mathrm{Sm} /{ }^{144} \mathrm{Nd}\right)_{\mathrm{CHUR}}{ }^{\text {present day }}=0.1967 ;\left({ }^{143} \mathrm{Nd} /{ }^{144} \mathrm{Nd}\right)_{\mathrm{CHUR}}{ }^{\text {present day }}=0.512638 ;\left({ }^{176} \mathrm{Lu} /{ }^{177}\right.$ 


\section{Highlights:}

- This study focuses on the syntectonic Neoproterozoic Upper Ruvubu Alkaline Plutonic Complex (URAPC, Burundi)

- The petrological, geochemical and isotope study emphasizes the processes leading to its formation

- Fractional crystallization, crustal assimilation/contamination, and latemagmatic/hydrothermal alteration are evidenced

- The two silicate magmatic series and the carbonatite appear cogenetic 


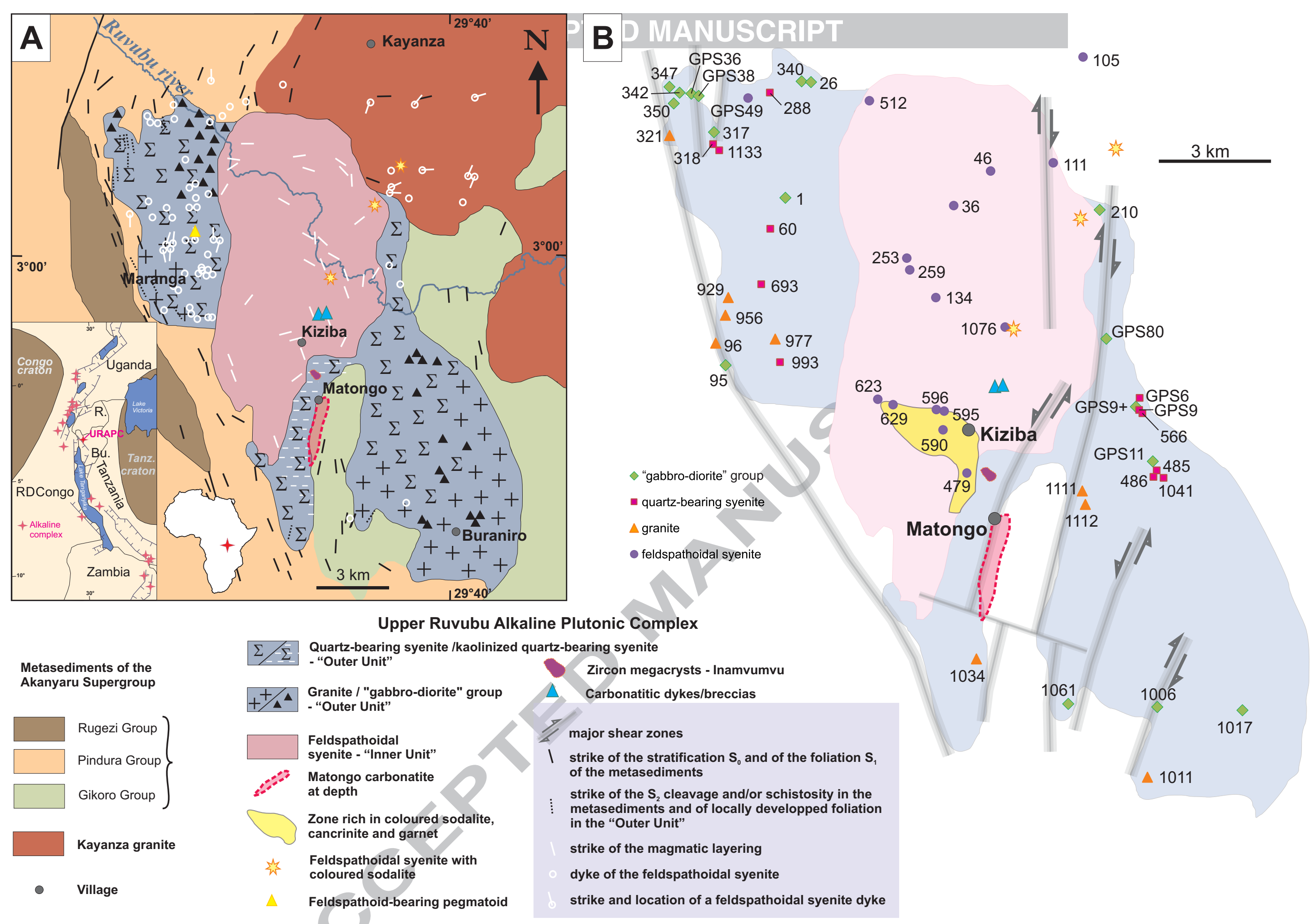




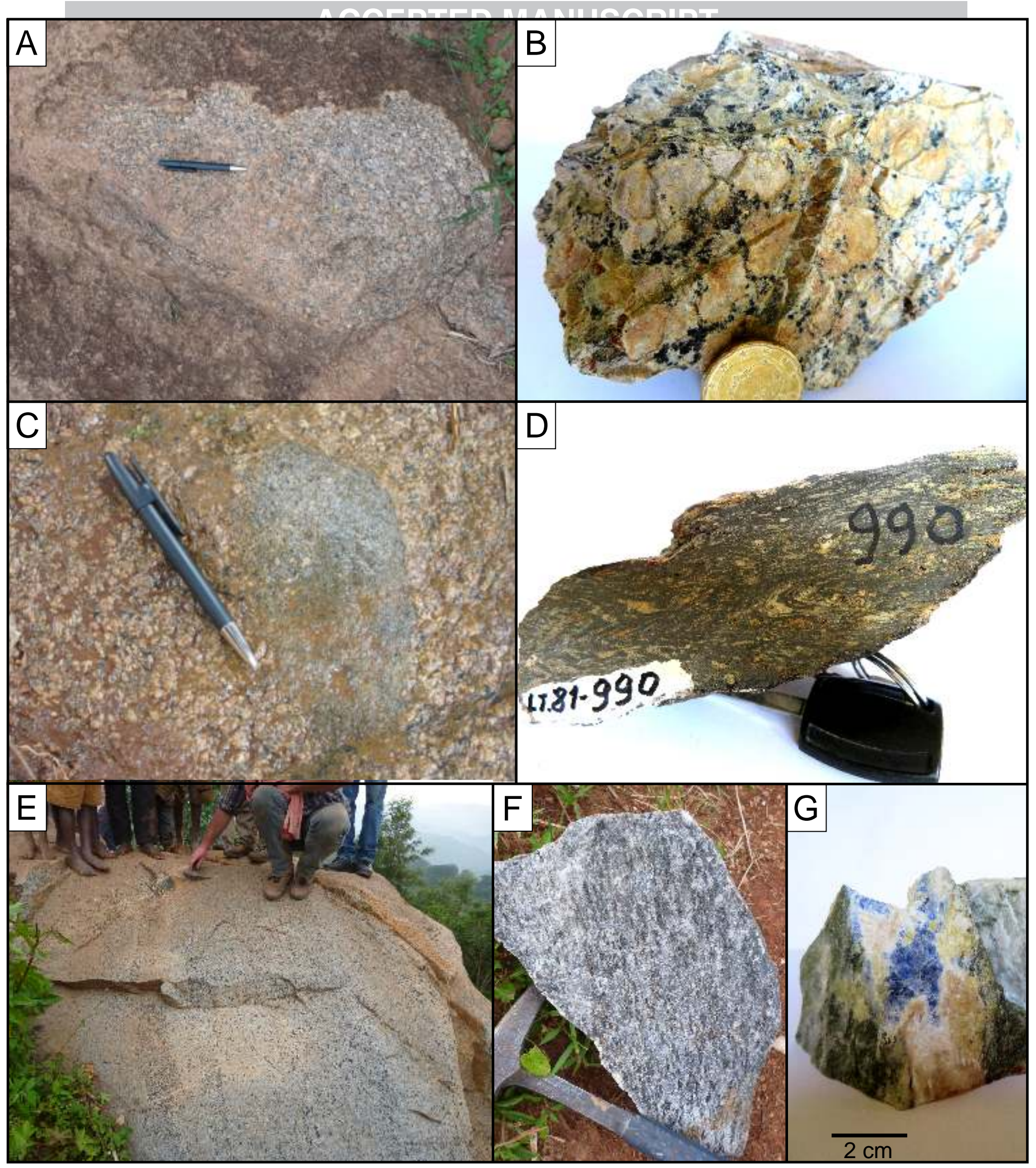




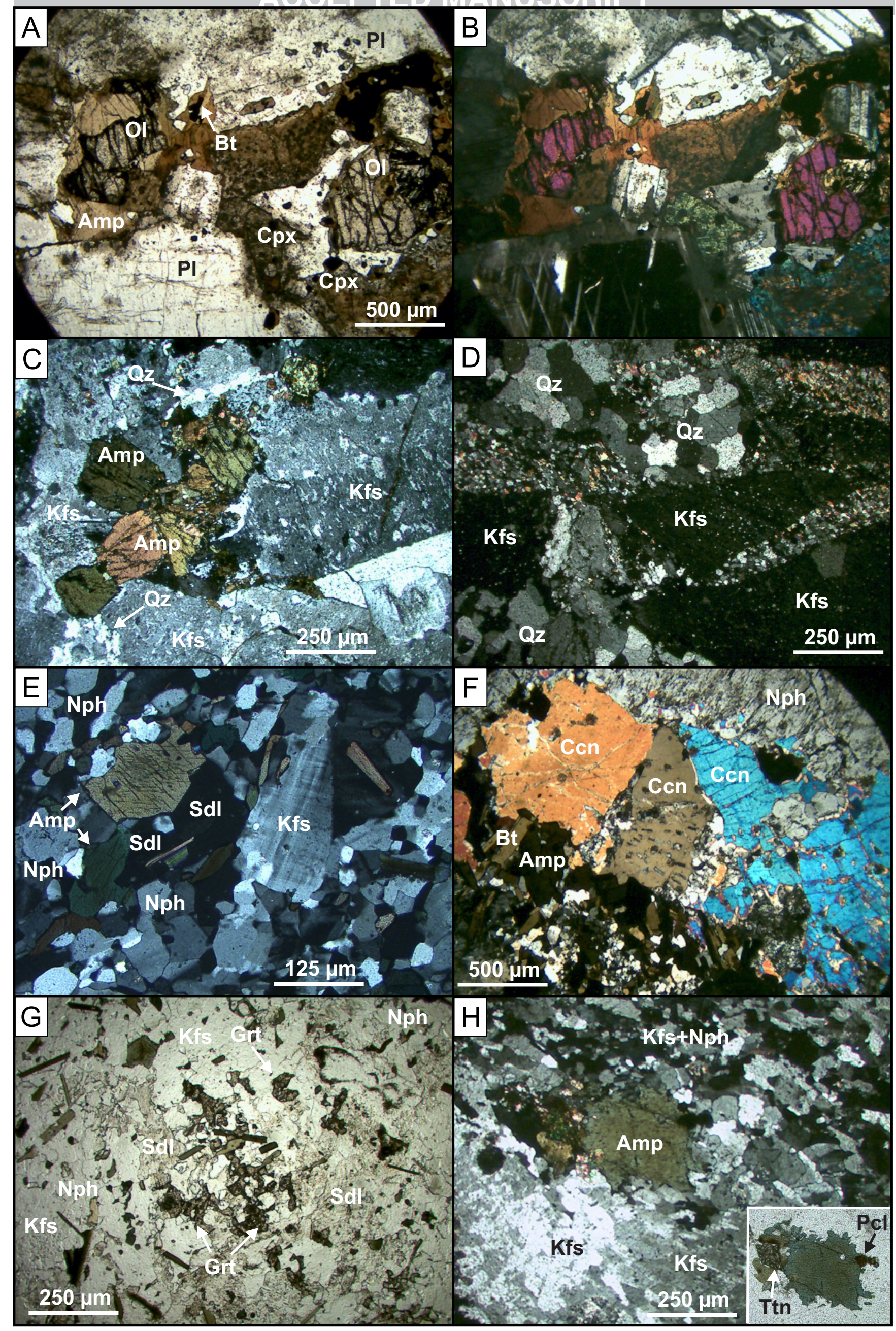


A

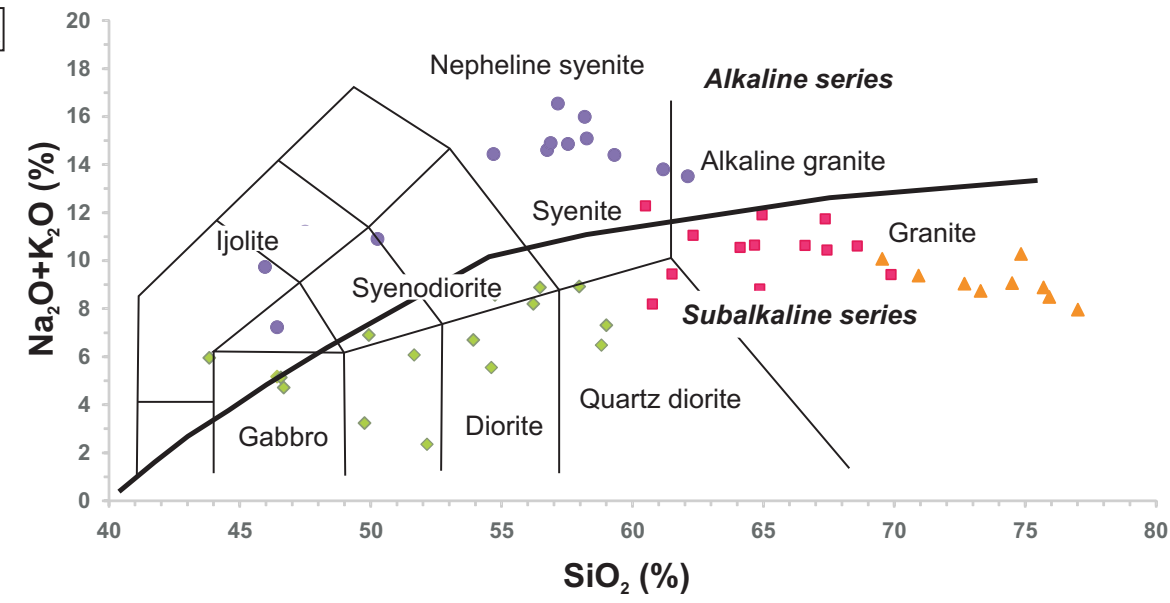

B

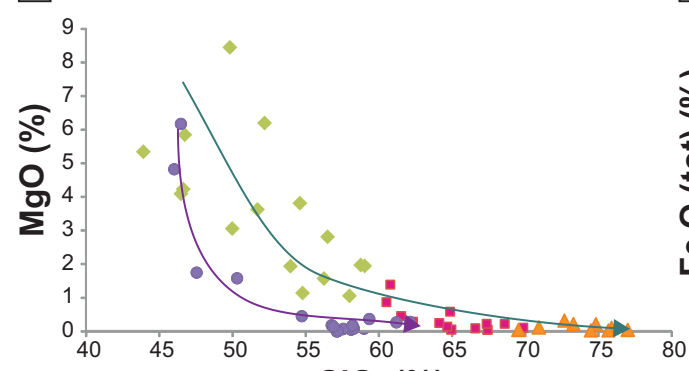

$\mathrm{SiO}_{2}(\%)$

E

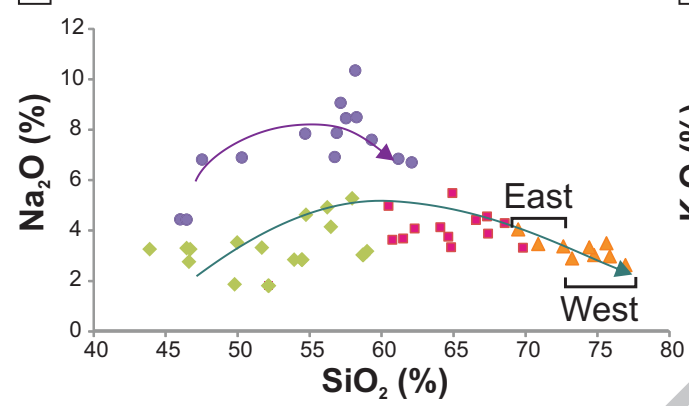

$\mathrm{H}$

Ko
C

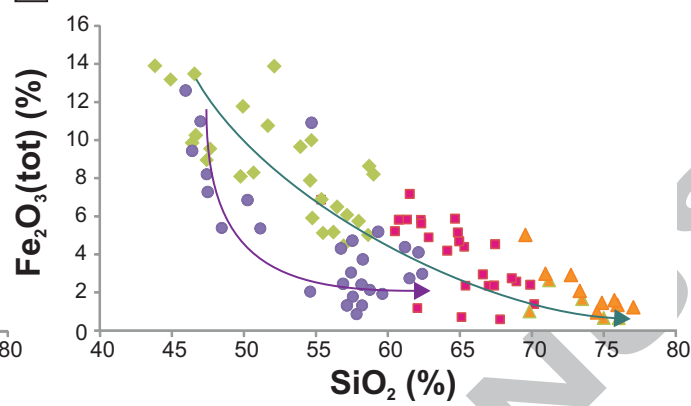

F

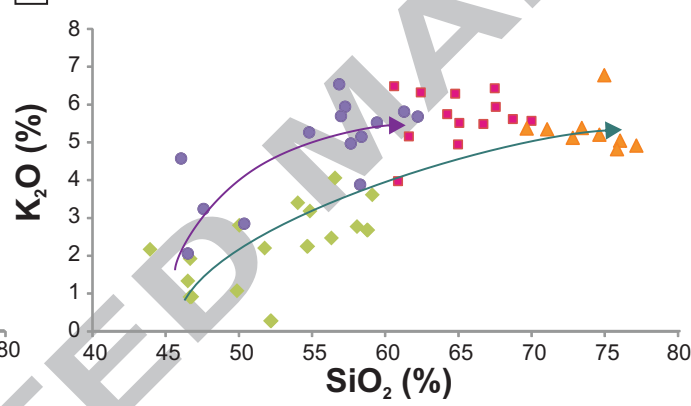

(1)

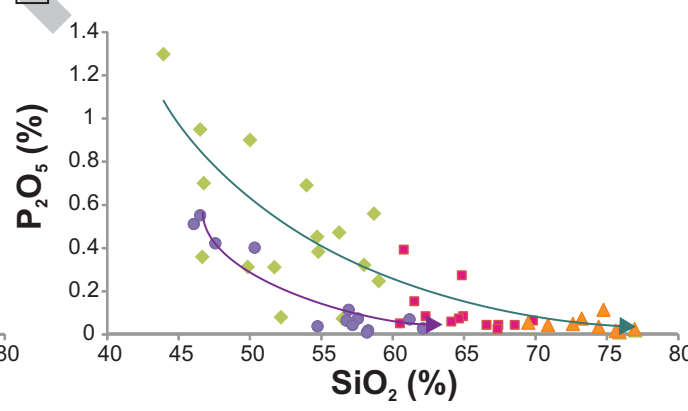

L

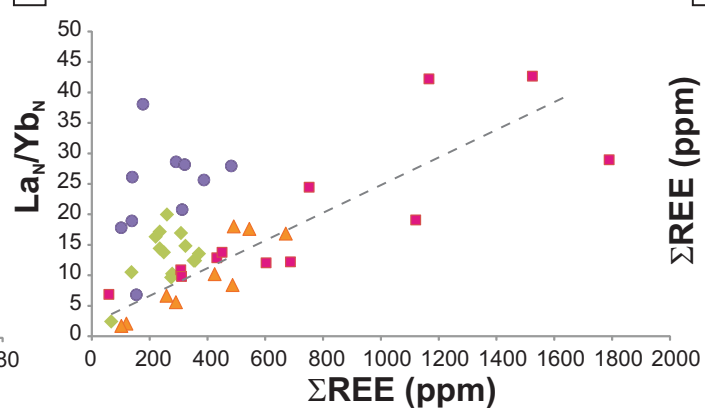

D

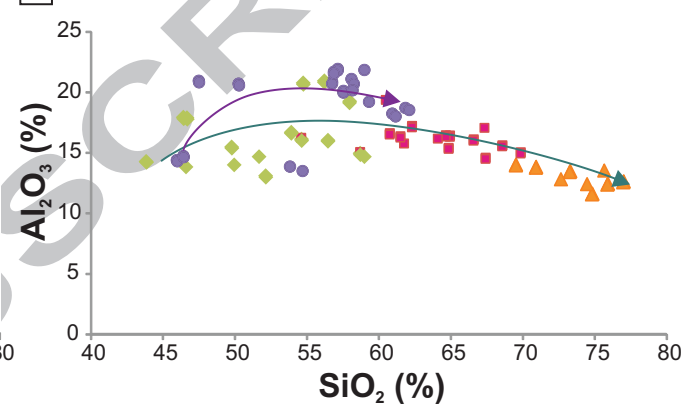

G

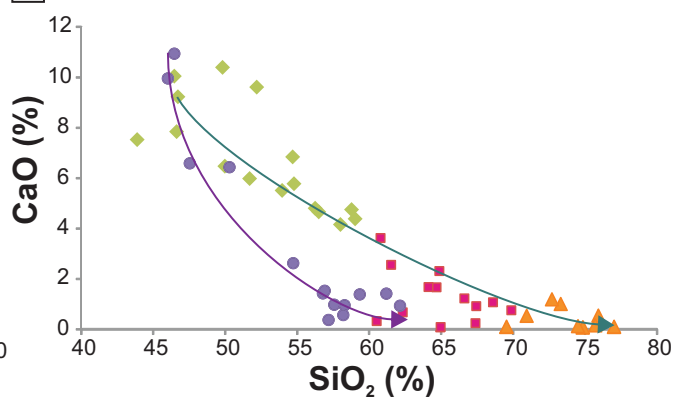

J

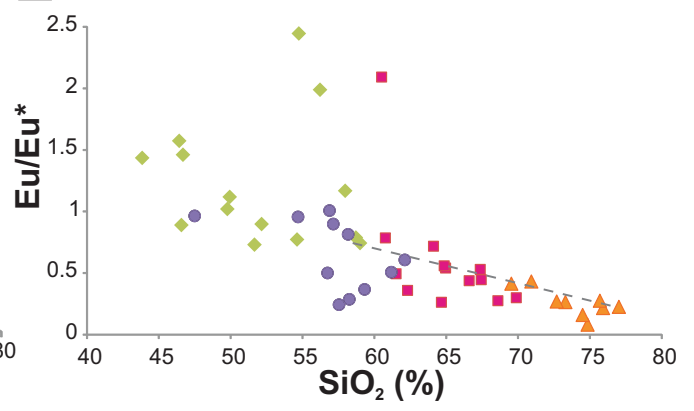

M

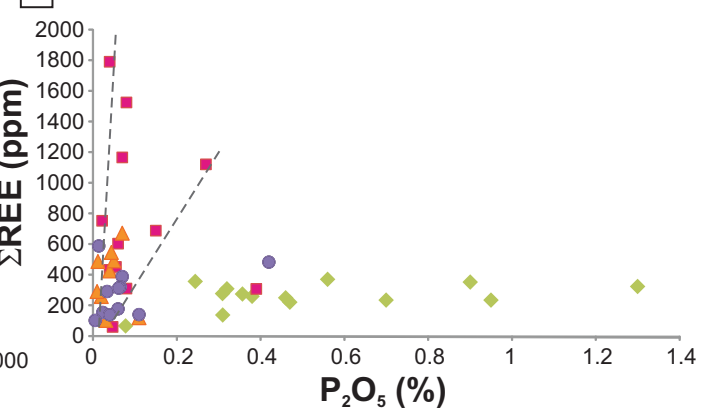



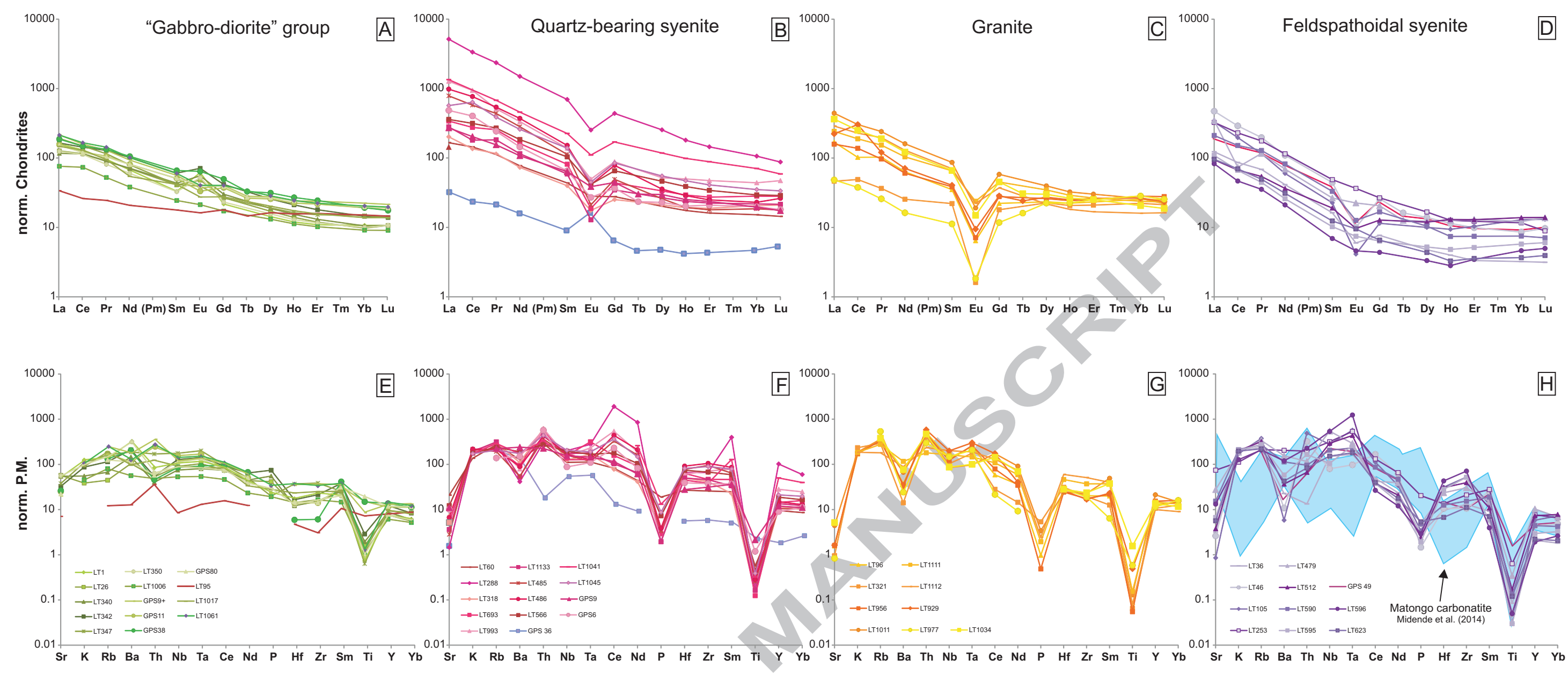

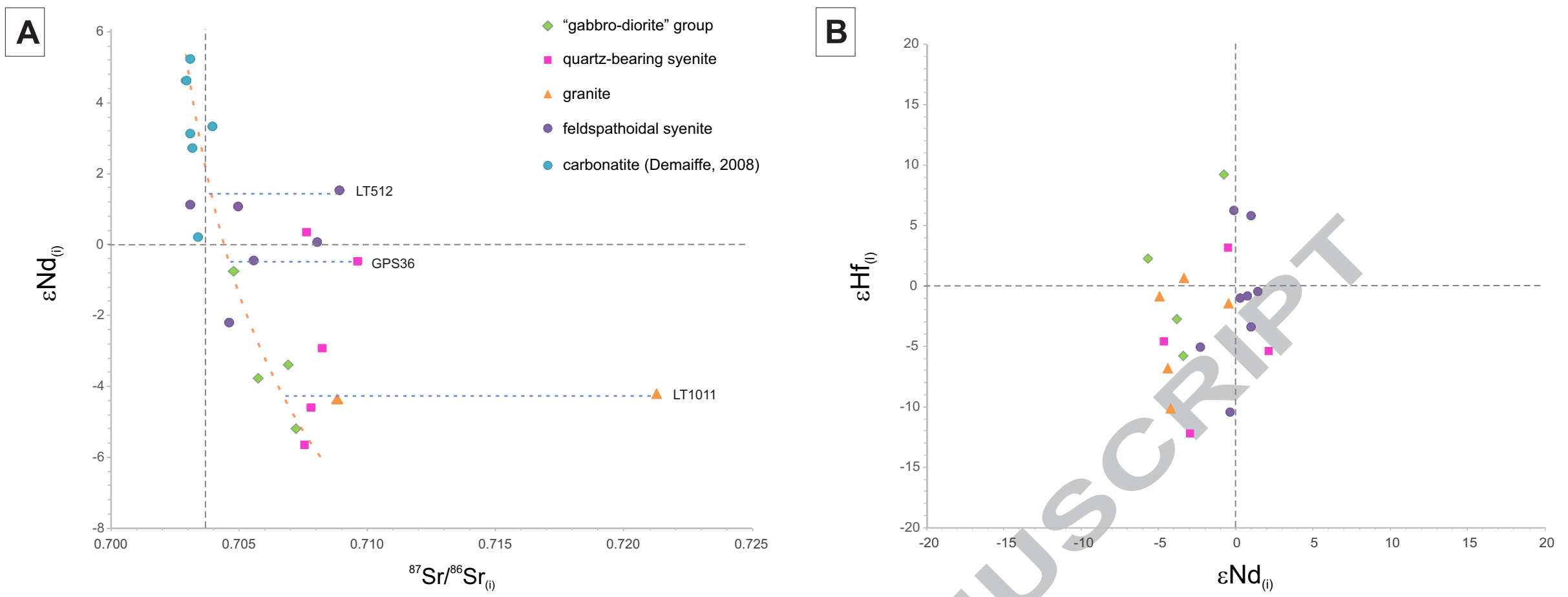

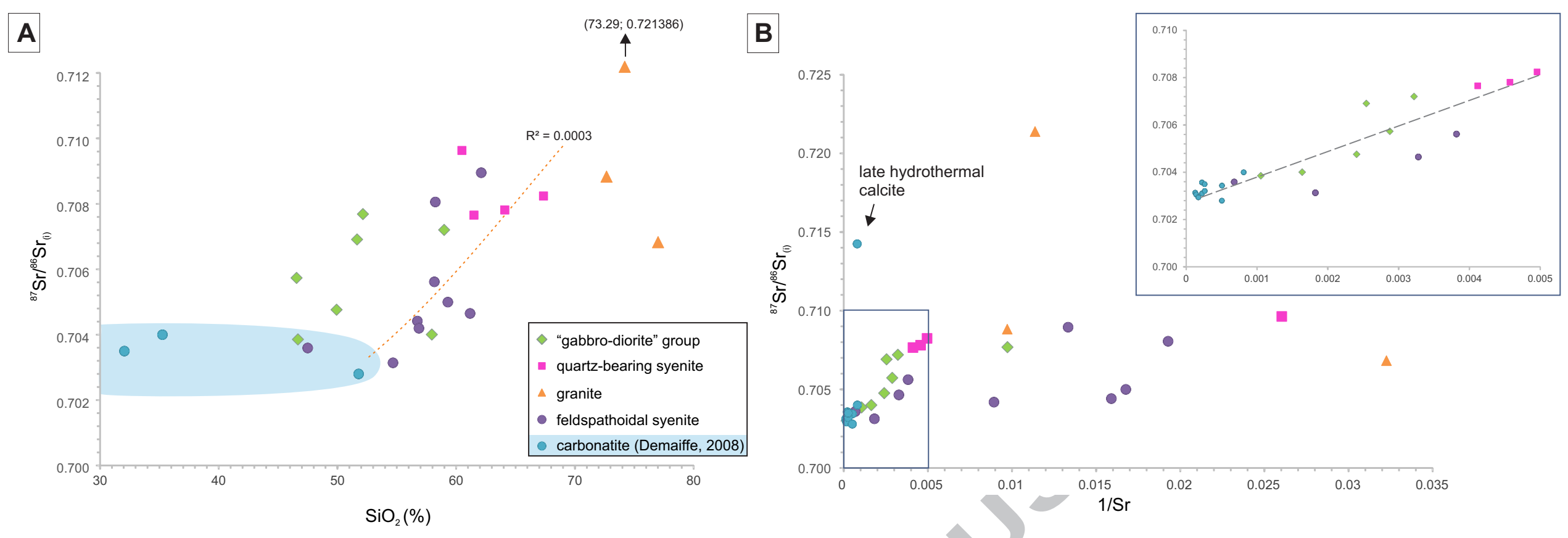
A

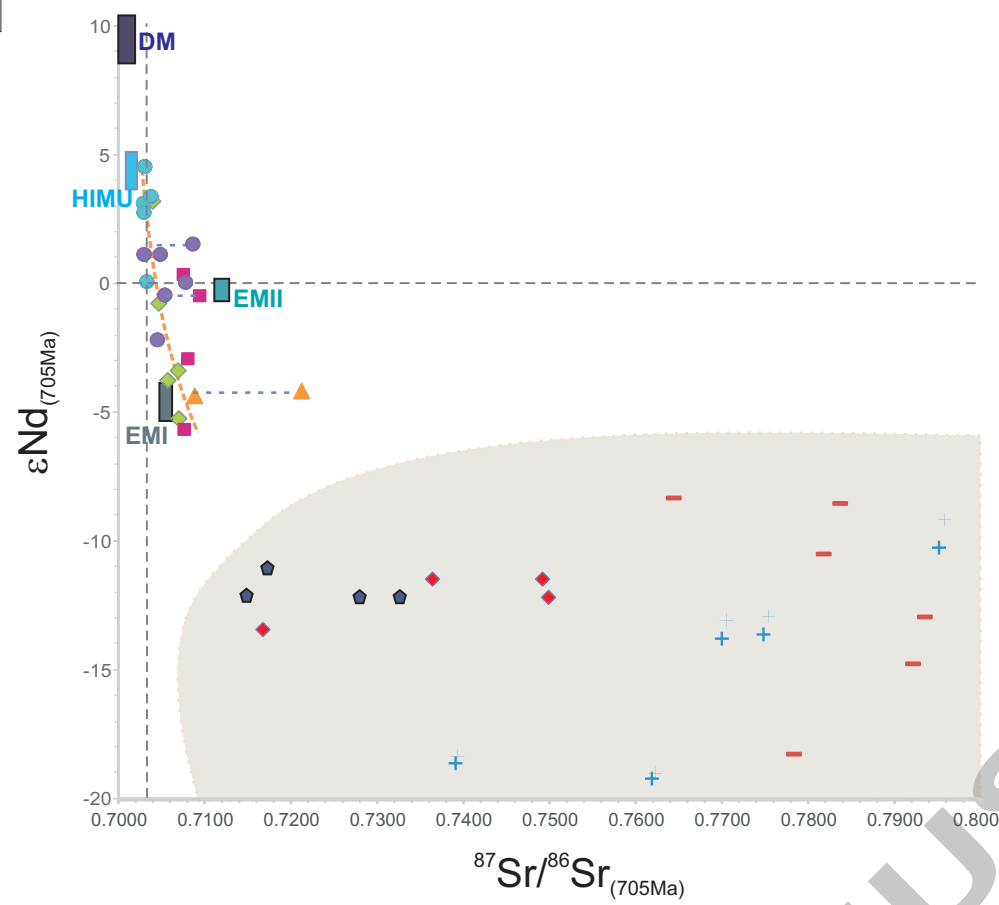

Country-rocks in the Karagwe-Ankole (KAB) and Kibara (KIB) Belts

- mafic rocks KIB (Debruyne et al., 2015)

+ felsic rocks KIB (Debruyne et al., 2015)

- metasediments KIB (Debruyne et al., 2015)

- felsic rocks (Kabanga-Musongati alignment) - KAB (Tack et al., 1994)

\section{URAPC rocks}

"gabbro-diorite" group

- quartz-bearing syenite

B
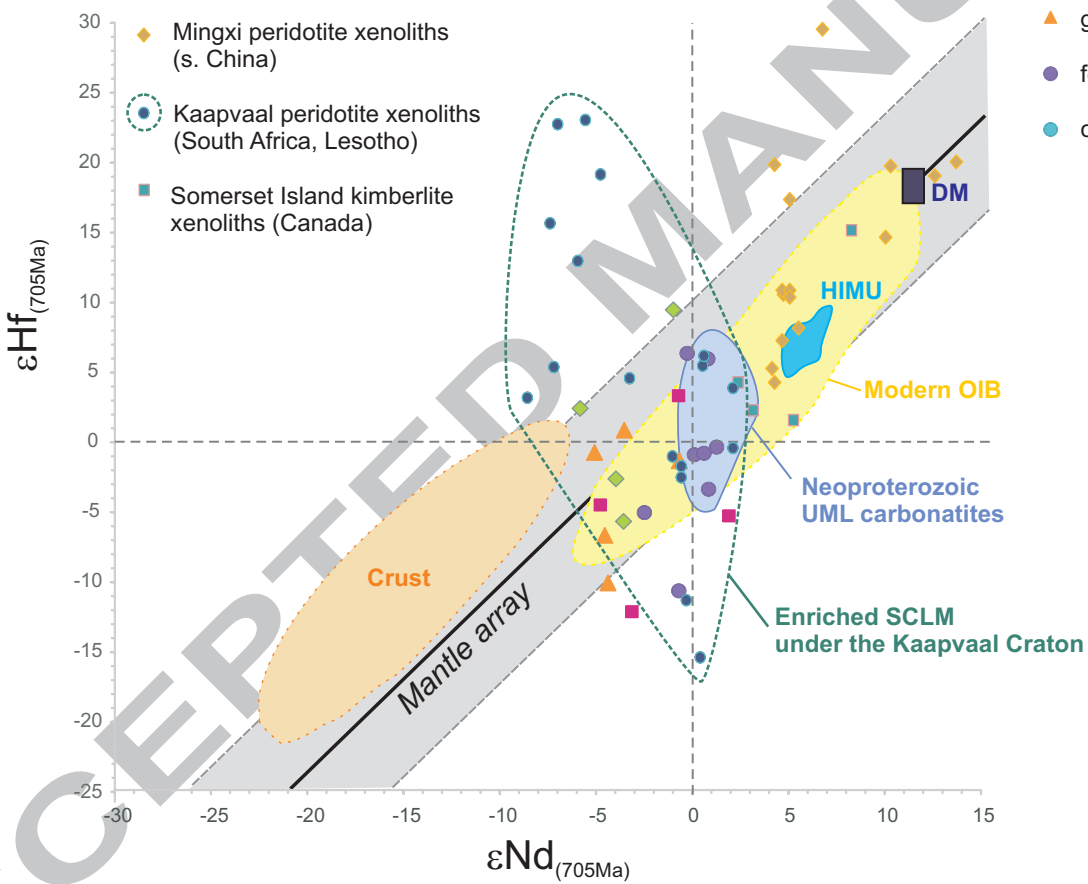

$\triangle$ granite

- feldspathoidal syenite

- carbonatite (Demaiffe, 2008) 